\title{
МИНЕРАЛОГИЧЕСКИЕ ОСОБЕННОСТИ И Р-Т УСЛОВИЯ МЕТАМОРФИЗМА НЕОПРОТЕРОЗОЙСКИХ МЕТАБАЗИТОВ В БАССЕЙНАХ РЕК ТЫРАДА И МАЛАЯ КАДРА, ЕНИСЕЙСКИЙ КРЯЖ
}

\author{
Никитин Радим Николаевич, \\ radim.geo@mail.ru \\ Национальный исследовательский Томский государственный университет, \\ Россия, 634050, г. Томск, ул. Ленина, 36.
}

\begin{abstract}
Актуальность. На сегодняшний день считается, что распространенные в заангарской части Енисейского кряжа метабазитовые породные ассоциации являются производными процессов рифртогенеза, вызванных плюмовой активностью и распадом суперконтинента Родиния на рубеже 1100-700 млн лет назад. При этом данные по их абсолютному возрасту являются предметом дискуссий. В статье рассматриваются неопротерозойские метаморфические события на примере термодинамических особенностей формирования исследуемых амфиболитовых проявлений, обсуждается вопрос их места в геодинамической модели образования Енисейского кряжа и роли син/постколлизионного гранитоидного магматизма в омоложении датированного возраста заангарских амфриболитов.

Цель: установить главный минеральный парагенезис амфиболитов и их вторичную минерализацию; определить термодинамические условия метаморффизма и его основные этапы; соотнести характер метаморфризма с метаморфическими событиями региона и определить его роль в формировании современного облика Енисейского кряжа; выявить причины, отвечающие за несоответствие полученного возраста изучаемы ах амфиболитов по Ar-Ar изотопии известньмм на сегодняшний день датировкам метабазальтов Заангарья.

Объект: амфиболиты шумихинского метапикрит-базальтового комплекса, входящего в состав малогаревской метасерии позднеархейского (?) возраста, залегающие в пластах карбонатных пород и кристаллических сланцев в бассейнах рек Тырада и Малая Кадра (притоков Теи и Панимбы соответственно).

Методы. Химический состав минеральных фаз изучен с использованием аналитического комплекса для растровой электронной микроскопии и микроанализа на базе сканирующего электронного микроскопа TESCAN VEGA II LMU, совмещенного с рентгеновским энергодисnерсионным микроанализатором Oxford INCA Energy 350, в центре коллективного пользования «Аналитический центр геохимии природных систем» Национального исследовательского Томского государственного университета. На основании этих данных были рассчитаны кристаллохимические формулы минералов, построены классификационные диаграммы и диаграммы геотермобарометров.

Результаты. Установлен общий парагенезис амфиболитов исследуемых проявлений: $H b l+P I \quad\left(X_{A n}=0,28-0,38\right)+Q z+I I m$ (Sph)+Fsp c вторичным локальным развитием Act, Zo, Bt, Ms u Chl. Термодинамические параметры метаморфизма метабазитов соответствуют условиям низкотемпературных зон амфибболитовой фации (555-475 ${ }^{\circ} \mathrm{C}, 5-7,5$ кбар) с динамикой повышения давления на общем фоне постепенного остывания. Амфиболиты являются производными коллизионного метаморфизма ( 880-800 млн лет), проявленного в условиях аккреции ранее отколовшихся тектонических блоков к Сибирскому кратону. Локальное развитие калишпатизации, актинолитизации и хлоритизации $\left(344-199{ }^{\circ} \mathrm{C}\right)$ относится к наложенным процессам в условиях повторного разогрева и может быть связано с завершающей стадией гренвильских тектонических событий, сопровождавшихся син/постколлизионным гранитоидным магматизмом (үRзsta, 760-630 млн лет), что могло стать причиной омоложения возраста исследуемых метабазитов (707-675 млн лет).
\end{abstract}

\section{Ключевые слова:}

Амфриболиты, неопротерозойский коллизионный метаморфизм, эпидот-амфиболитовая фрация, P-Т условия, возраст метаморфииза, Енисейский кряж.

\section{Введение}

Мафитовый магматизм считается индикатором тектонических событий в обстановках спрединга, субдукции и внутриплитных горячих точек [1-3]. Пикрит-базальтовая и субщелочная базальтоидная магматическая активность, проявленная на югозападном обрамлении Сибирского кратона, могла быть связана с мезопротерозойским растяжением литосферы в результате внедрения высокотемпературного материала [4-6]. При этом продукты его геологической деятельности, подвергнувшиеся метаморфизму, заключают в себе разные стадии развития палеоокеанов [7]. Такие метабазитовые проявления распространены в складчато-надвиговом поясе Енисейского кряжа, где они залегают среди метаморфизованных толщ Заангарья и Ангаро-Канского выступа в виде протерозойских субсогласных тел, приурочен- ных к Татаро-Ишимбинскому глубинному разлому и Приенисейской сдвиговой зоне [8-12]. На сегодняшний день не существует единого мнения по поводу условий и времени их образования. По одним данным амфиболитовые проявления имеют позднеархейский возраст и являются производными рассеянного рифтогенеза в условиях гранулитовой и гранатсиллиманитовой зон амфиболитовой фации [13], по другим - неопротерозойскими рифтогенными метаморфитами [9, 10, 14], сформированными в условиях амфиболитовой и эпидот-амфиболитовой фаций метаморфизма в обстановке растяжения и сжатия континентальной коры [15]. Установление целостной картины протерозойских метаморфических событий региона, как отражение геодинамических режимов, а также выявление причин реальной проблемы с неоднозначностью абсолютного возраста метабазитовых тел Заангарья и поиск маркеров, указывающих на 
перестройку изотопной системы в амфиболах, представляют собой фундаментальную и практическую ценность исследования. Для этого мы изучаем минеральные ассоциации амфиболитовых проявлений и Р-Т условия их метаморфизма.

\section{Объект исследования}

Енисейский кряж является докембрийским орогеном на юго-западной части Сибирской платформы и представляет собой два различных по строению сегмента: Заангарье и Ангаро-Канский блок. Формирование складчато-надвигового пояса Заангарья происходило в обстановке коллизии одного или нескольких террейнов к окраине Сибирского кратона в интервале 1100-900, 900-850 и 800-600 млн лет назад [16-22]. При этом считается, что формирование рифтогенных структур в пределах Татаро-Ишимбинской зоны разломов Енисейского кряжа происходило в три стадии (750, 700 и 650-670 млн лет) и сопровождалось внутриплитным магматизмом, а также образованием метабазитов Приангарья и Тейско-Чапского прогиба в северной части Енисейского кряжа $[9,10,14]$.

Изучаемые метабазальты расположены в средней части Заангарья в пределах Татаро-Ишимбинской зоны разломов и относятся к шумихинскому метапикртитбазальтовому комплексу в составе малогаревской метасерии позднеархейского (?) возраста и прорывают карбонатные породы (мрамора, кальцифиры) и кристаллические сланцы в долинах рек Тырада и Малая Кадра, притоков Теи и Панимбы соответственно (рис. 1). По своим геохимическим признакам исследуемые метавулканиты сопоставимы с толеитовыми производными E-MORB-магматизма. Предполагается, что их развитие происходило в сложной геодинамической обстановке задугового бассейна и взаимодействия мантийного/астеносферного диапира с материковой окраиной и/или фрагментами обогащенной океанической литосферы. [23]. Метабазиты представляют собой ограниченные по площади ареалы субсогласных будинированных пластинообразных тел (до 2000×30 м) амфиболитов. Это мелко-среднезернистые породы темнозеленого цвета с массивной, реже сланцеватополосчатой текстурой. В шлифах они имеют нематобластовую равномерно-зернистую структуру и представлены преимущественно зеленой роговой обманкой и плагиоклазом с подчиненной ролью кварца, биотита и рудных минералов.

По результатам изотопного Ar-Ar-анализа время образования амфибола из метабазитовых пород соответствует $707 \pm 6$ и $544 \pm 5$ млн лет для амфиболитовых образований реки Тырада и $675 \pm 10$ млн лет для метабазитов в долине реки Кадра [23]. Наблюдаемое низкотемпературное спектральное плато на 544 млн лет, вероятно, свидетельствует о перестройке изотопной системы минерала в условиях ретроградного метаморфизма, которое могло быть связанного с надвиговой тектоникой [24] и проявлением более позднего внутриплитного магматизма в пределах Енисейского кряжа. Данные по изотопному составу неодима $\left(\sim 1,4-2,2\right.$ млрд лет) и изотопных отношений ${ }^{87} \mathrm{Sr}^{86} \mathrm{Sr}_{\mathrm{T}}$ отражают разнородный характер субстрата, участво- вавшего в породообразовании, и позволяют говорить о смешении мантийных протолитов с компонентами земной коры [23].

\section{Методика исследования}

Данные по количественному анализу минеральных фаз исследуемых амфиболитов были получены при помощи аналитического комплекса сканирующего электронного микроскопа VEGA II LMU, совмещенного с энергодисперсионным рентгеновским спектрометром модели INCA Energy 350. Пробоподготовка для данного вида исследования включала в себя изготовление образца размером не более $20 \times 20 \times 5$ мм путем отпиливания его от горной породы с последующей полировкой и чисткой поверхности, а также напылением слоя углерода толщиной $25 \pm 5$ нм.

При процедуре количественного анализа образец располагался строго перпендикулярно к пучку зонда под определенным углом к устройству $\mathrm{Si}(\mathrm{Li})$ детектора. Рабочее ускоряющее напряжение не менее 15 кВ, ток пучка 5 нА, размер пучка $500 \AA$. Результаты анализа визуализировались в виде спектра. Для получения прецизионных данных о химическом составе исследуемого объекта проводилась локализация области возбуждения, что дало значительно откорректированный спектр.

Для оценки термодинамических условий метаморфизма были использованы минеральные геотермобарометры: роговообманковый геотермобарометр [25], Amp-Pl геотермометр [26] и Amp-Pl геобарометры $[27,28]$, а также термометры для определения температур кристаллизации хлоритов [29-31]. Геотермобарометрия производилась на основании рассчитанных структурных формул минералов с использованием данных, полученных при помощи энергодисперсионного анализа. Расчет кристаллохимических формул проводился на 28 атомов кислорода для хлорита, на 23 для амфибола, на 11 для биотита и мусковита, на 8 для плагиоклаза и калиевого полевого шпата.

\section{Результать}

Нами были проанализированы тринадцать образцов метабазитовых проявлений в долинах рек Тырада (T-1/1, Т-1/4, Т-3/3, Т-3/5, Т-3/6, Т-4/2, Т-5/2, далее I) и Малая Кадра (K-7, K-9, K-10, K-11, K-12, K-13, далее II). В табл. 1 приведены их типичные представители и составы их главных породообразующих минералов. Было сделано до 60 точек рентгеноспектрального анализа на четырех-пяти участках в каждом отдельно взятом образце. В результате проведенных исследований установлен общий парагенезис амфиболитов двух исследуемых проявлений: $\mathrm{Hbl}$ (роговая обманка) + Pl (плагиоклаз, $\left.\mathrm{X}_{\mathrm{An}}=0,28-0,38\right)+\mathrm{Qz}$ (кварц) + Ilm (ильменит) (рис. 2). На него накладываются процессы, повлекшие развитие Sph (сфена) и частичной калишпатизации, проявленной в виде реликтов зерен ортоклаза (Or) или залеченных им микротрещинок. Локальное развитие Bt (биотита), Ms (мусковита), Chl (хлорита), a затем Act (актинолита) и Zo (цоизита) присуще только отдельным зонам амфиболитов бассейна р. Тырада и отражает постметаморфические наложенные процессы. 

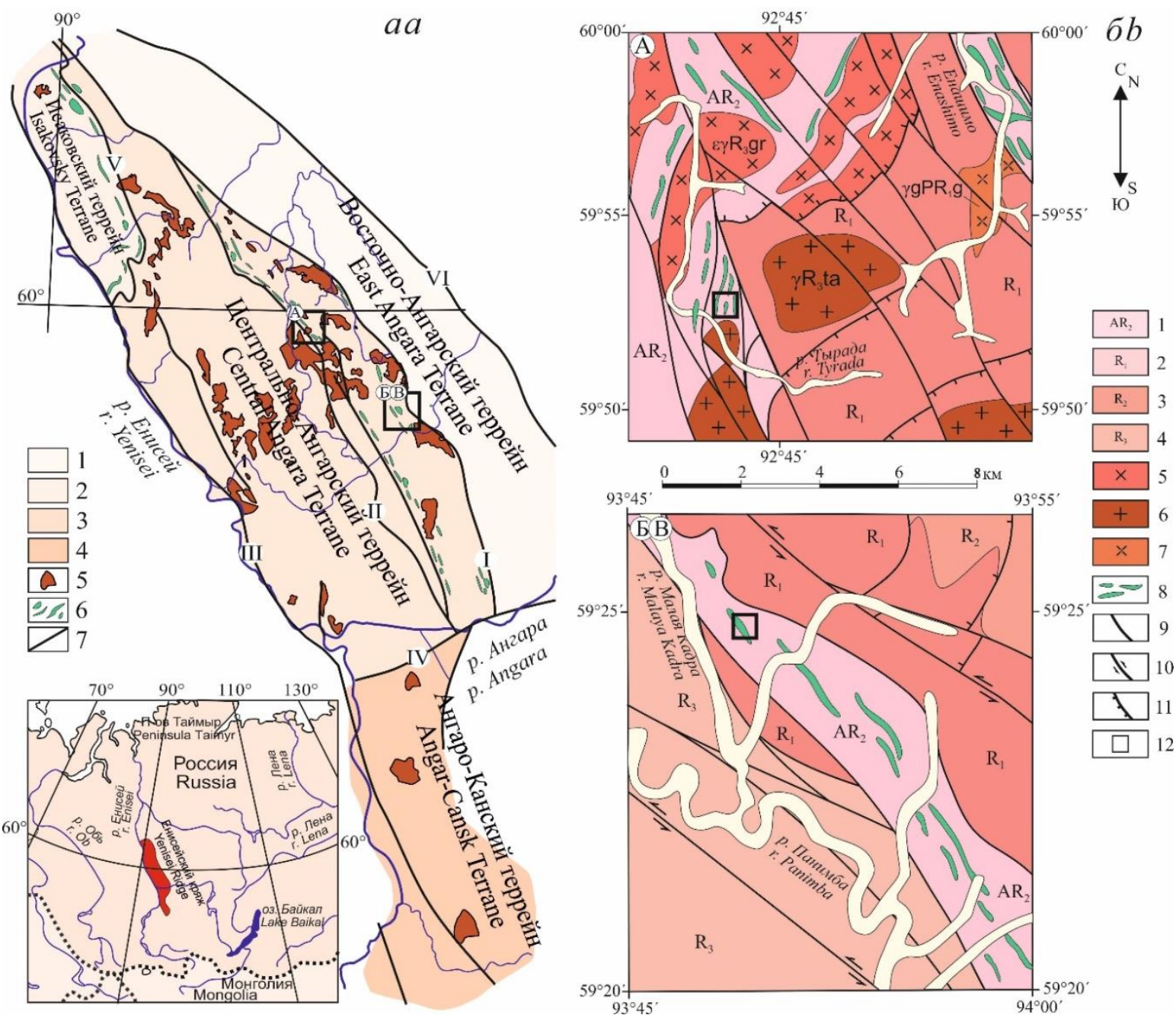

Рис. 1. Геологическая позиция метабазитовых пород Заангарья: а) структурно-тектоническая схема Енисейского кряжа [17]: 1 - мезо- и неопротерозойские метаосадочные комплексы Восточно-Ангарского террейна; 2 неопротерозойские метаосадочные и вулканогенные комплексы Исаковского террейна; 3 - архейские, палеомезо- и неопротерозойские метаосадочные комплексы Центрально-Ангарского террейна; 4 - архейские и палеопротерозойские гранулитовые и гнейсовые комплексы Ангаро-Канского террейна; 5 - гранитоидные массивы; 6 - пояса распространения метабазитовых пород; 7 - региональные зоны разломов: I - Ишимбинская, II - Татарская, III - Енисейская, IV - Нижсне-Ангарская, V-Исаковская, VI - Ангаро-Бахтинская. На врезке показано географическое расположение Енисейского кряжа; б) схемы геологического строения в бассейнах рек Тырада (А) и Малая Кадра (Б), составлены по материалам геологических съемок (А.А. Стороженко, В.К. Зуев, 1981; А.И. Хисамутдинов, 1990; А.А. Стороженко, Н.Ф. Васильев, 2003; В.М. Колямкин, Г.А. Середенко, 2006), 1 - плагиогнейсы, гнейсы, мраморы, амфиболиты малогаревского комплекса архея $\left(A R_{2}\right) ; 2-4$ - биотит-хлорит-серицитовые сланцыь, кварцевые и аркозовые метапесчаники кординской свиты (2), серицит-хлоритовые сланцы горбилокской и удерейской свит (3), филлиты шунтарской и потоскуйской свит (4) рифейского $\left(R_{1-3}\right)$ возраста; 5-7 - гранитоидные комплексы: гаревский (5), татарско-аяхтинский (6), гурахтинский (7); 8- амфиболиты; 9-11 - дизъюнктивные нарушения: субвертикальные разломы (9), сдвиги (10), надвиги (11); 12 -места отбора проб

Fig. 1. Geological position of Transangarian metabasites: a) structural tectonic scheme of Yenisei ridge [17]: 1 - meso-and neoproterozoic metasediment complexes of East Angarian terrain; 2 - neoproterozoic metasediment and volcanogenic complexes of Isakovsky terrain; 3 - paleo-, meso- and neoproterozoic metasediment complexes of Central Angarian terrain; 4 - archean and paleoproterozoic granulitic and gneiss complexes of Angarian-Kansk terrain; 5 - granitoid massifs; 6 - metabasites distribution belts; 7 - regional fault zones: I - Ishimbinskaya, II Tatarskaya, III - Yeniseiskaya, IV - Nizhne-Angarskaya, V-Isakovskaya, VI-Angaro-Bakhtinskaya. Geographical location of Yenisei ridge is shown on the incut; $b$ ) schemes of geological structure of areas of Tyrada (A) and Malaya Kadra (B) according to materials of geological surveys (A.A. Storozhenko, V.K. Zuev, 1981; A.I. Hisamutdinov, 1990; A.A. Storozhenko, N.F. Vasilev, 2003; V.M. Kolyamkin, G.A. Seredenko, 2006), 1 -plagiogneisses, gneisses, marbles, amphibolites of malogarevsky complex $\left(A R_{2}\right) ; 2-4$ - biotite-chlorite-sericite schists, quartzose and arkose metasandstones (kordinskaya suite) (2), sericite-chlorite schists (gorbilokskaya and udereyskaya suites) (3), phyllites (shuntarskaya and potoskuyskaya suites) (4) all $R_{1-3} ; 5-7-$ granitoid complexes: garevsky (5), tatar-ayahtinsky (6), gurakhtinsky (7); 8 - amphibolites; 9-11 - disjunctive faults: subvertical faults (9), strike-slip faults (10), thrust faults (10); 12 - sampling points 
Таблица 1. Химический состав (мас. \%) и структурные формуль минералов представительных амфиболитов

Table 1. Chemical composition (wt. \%) and structural formula of minerals in the representative amphibolites

\begin{tabular}{|c|c|c|c|c|c|c|c|c|c|c|c|c|}
\hline \multirow{3}{*}{$\begin{array}{l}\text { Компонент } \\
\text { Component }\end{array}$} & \multicolumn{12}{|c|}{ Метабазитовое проявление в бассейне р. Тырада/Metabasites from the Tyrada river basin } \\
\hline & \multicolumn{2}{|c|}{$\mathrm{T}-1 / 4$} & \multicolumn{5}{|c|}{$\mathrm{T}-1 / 1$} & \multicolumn{5}{|c|}{$\mathrm{T}-3 / 3$} \\
\hline & \multicolumn{2}{|c|}{ Act } & \multicolumn{2}{|c|}{$\mathrm{Hbl}$} & \multicolumn{2}{|c|}{ Pl } & $\mathrm{Bt}$ & \multicolumn{2}{|c|}{$\mathrm{Hbl}$} & \multicolumn{2}{|c|}{$\mathrm{Pl}$} & \multirow{2}{*}{$\frac{\mathrm{Bt}}{39,53}$} \\
\hline $\mathrm{SiO}_{2}$ & 55,25 & 55,32 & 43,73 & 43,25 & 58,40 & 58,69 & 36,31 & 42,36 & 42,15 & 61,08 & 58,56 & \\
\hline $\mathrm{TiO}_{2}$ & 0,00 & 0,00 & 0,35 & 0,43 & 0,00 & 0,00 & 0,58 & 0,49 & 0,65 & 0,00 & 0,00 & 2,13 \\
\hline $\mathrm{Al}_{2} \mathrm{O}_{3}$ & 1,68 & 3,08 & 13,35 & 13,16 & 25,63 & 25,87 & 17,56 & 13,46 & 12,47 & 23,71 & 22,94 & 16,33 \\
\hline $\mathrm{FeO}$ & 10,63 & 11,54 & 15,73 & 15,17 & 0,24 & 0,28 & 18,26 & 18,87 & 18,14 & 0,23 & 0,39 & 21,64 \\
\hline $\mathrm{MnO}$ & 0,39 & 0,49 & 0,23 & 0,23 & 0,00 & 0,00 & 0,00 & 0,32 & 0,24 & 0,00 & 0,00 & 0,00 \\
\hline $\mathrm{MgO}$ & 17,34 & 16,75 & 9,83 & 9,64 & 0,00 & 0,00 & 14,97 & 7,62 & 8,32 & 0,00 & 0,00 & 12,18 \\
\hline $\mathrm{CaO}$ & 12,92 & 13,03 & 12,10 & 11,80 & 7,89 & 7,70 & 0,00 & 11,05 & 11,43 & 5,68 & 5,53 & 0,00 \\
\hline $\mathrm{Na}_{2} \mathrm{O}$ & 0,00 & 0,00 & 1,27 & 1,47 & 6,93 & 6,96 & 0,31 & 1,89 & 1,46 & 7,45 & 7,35 & 0,00 \\
\hline $\mathrm{K}_{2} \mathrm{O}$ & 0,00 & 0,00 & 0,93 & 0,96 & 0,14 & 0,00 & 7,35 & 0,44 & 0,61 & 0,18 & 0,00 & 9,47 \\
\hline Сумма/Amount & 98,21 & 100,21 & 97,52 & 96,11 & 99,67 & 97,99 & 95,34 & 96,50 & 95,47 & 98,33 & 94,77 & 101,29 \\
\hline$(\mathrm{O})$ & $(23)$ & (23) & (23) & (23) & (8) & (8) & (11) & (23) & $(23)$ & (8) & (8) & (11) \\
\hline $\mathrm{Si}$ & 7,826 & 7,708 & 6,515 & 6,530 & 2,631 & 2,633 & 2,715 & 6,469 & 6,500 & 2,750 & 2,739 & 2,834 \\
\hline $\mathrm{Ti}$ & 0,000 & 0,000 & 0,039 & 0,049 & 0,000 & 0,000 & 0,033 & 0,056 & 0,075 & 0,000 & 0,000 & 0,115 \\
\hline $\mathrm{Al}$ & 0,280 & 0,506 & 2,344 & 2,342 & 1,361 & 1,368 & 1,548 & 2,423 & 2,266 & 1,258 & 1,265 & 1,380 \\
\hline $\mathrm{Fe}$ & 1,259 & 1,345 & 1,960 & 1,915 & 0,000 & 0,000 & 1,142 & 2,410 & 2,339 & 0,009 & 0,015 & 1,297 \\
\hline $\mathrm{Mn}$ & 0,047 & 0,058 & 0,029 & 0,029 & 0,009 & 0,011 & 0,000 & 0,041 & 0,031 & 0,000 & 0,000 & 0,000 \\
\hline $\mathrm{Mg}$ & 3,661 & 3,478 & 2,183 & 2,169 & 0,000 & 0,000 & 1,668 & 1,734 & 1,912 & 0,000 & 0,000 & 1,302 \\
\hline $\mathrm{Ca}$ & 1,961 & 1,945 & 1,931 & 1,909 & 0,381 & 0,370 & 0,000 & 1,808 & 1,888 & 0,274 & 0,277 & 0,000 \\
\hline $\mathrm{Na}$ & 0,000 & 0,000 & 0,367 & 0,430 & 0,605 & 0,605 & 0,045 & 0,560 & 0,437 & 0,650 & 0,666 & 0,000 \\
\hline $\mathrm{K}$ & 0,000 & 0,000 & 0,177 & 0,185 & 0,008 & 0,000 & 0,701 & 0,086 & 0,120 & 0,010 & 0,000 & 0,866 \\
\hline $\mathrm{X}_{\mathrm{Fe}}$ & 0,256 & 0,279 & 0,473 & 0,469 & - & - & 0,406 & 0,581 & 0,550 & - & - & 0,499 \\
\hline $\mathrm{X}_{\mathrm{Mg}}$ & 0,744 & 0,721 & 0,527 & 0,531 & - & - & 0,594 & 0,419 & 0,450 & - & - & 0,501 \\
\hline$X_{\text {An }}$ & 1,000 & 1,000 & 0,780 & 0,756 & 0,383 & 0,379 & - & 0,737 & 0,772 & 0,293 & 0,294 & - \\
\hline \multirow{3}{*}{$\begin{array}{l}\text { Компонент } \\
\text { Component }\end{array}$} & \multicolumn{12}{|c|}{ Метабазитовое проявление в бассейне р. Малая Кадра/Metabasites from the Malaya Kadra river basin } \\
\hline & \multicolumn{4}{|c|}{$\mathrm{K}-7$} & \multicolumn{4}{|c|}{ K-9 } & \multicolumn{4}{|c|}{ K-13 } \\
\hline & \multicolumn{2}{|c|}{$\mathrm{Hbl}$} & & & & & & & & & & \\
\hline $\mathrm{SiO}_{2}$ & 44,62 & 44,12 & 60,60 & 63,21 & 43,62 & 44,66 & 59,83 & 62,47 & 43,17 & 45,57 & 59,22 & 59,88 \\
\hline $\mathrm{TiO}_{2}$ & 0,60 & 0,61 & 0,00 & 0,00 & 0,41 & 0,41 & 0,00 & 0,00 & 0,36 & 0,41 & 0,00 & 0,00 \\
\hline $\mathrm{Al}_{2} \mathrm{O}_{3}$ & 13,44 & 12,60 & 25,70 & 24,32 & 12,24 & 13,33 & 23,44 & 24,74 & 13,26 & 12,18 & 24,50 & 24,28 \\
\hline $\mathrm{FeO}$ & 18,82 & 18,98 & 0,36 & 0,44 & 17,47 & 18,35 & 0,00 & 0,34 & 17,83 & 17,76 & 0,00 & 0,27 \\
\hline $\mathrm{MnO}$ & 0,23 & 0,27 & 0,00 & 0,00 & 0,27 & 0,00 & 0,00 & 0,00 & 0,26 & 0,25 & 0,00 & 0,00 \\
\hline $\mathrm{MgO}$ & 8,22 & 7,96 & 0,00 & 0,00 & 8,83 & 8,71 & 0,00 & 0,00 & 8,22 & 9,10 & 0,00 & 0,00 \\
\hline $\mathrm{CaO}$ & 11,74 & 11,73 & 7,31 & 5,31 & 11,53 & 11,98 & 5,46 & 5,86 & 11,78 & 11,92 & 6,67 & 6,46 \\
\hline $\mathrm{Na}_{2} \mathrm{O}$ & 1,59 & 1,38 & 7,85 & 8,28 & 1,36 & 1,49 & 8,39 & 8,63 & 1,38 & 1,35 & 7,49 & 7,68 \\
\hline $\mathrm{K}_{2} \mathrm{O}$ & 0,36 & 0,37 & 0,00 & 0,00 & 0,24 & 0,27 & 0,00 & 0,00 & 0,31 & 0,26 & 0,00 & 0,00 \\
\hline Сумма/Amount & 99,62 & 98,02 & 101,82 & 101,56 & 95,97 & 99,20 & 97,12 & 102,04 & 96,57 & 98,80 & 97,88 & 98,57 \\
\hline $\mathrm{n}(\mathrm{O})$ & $(23)$ & $(23)$ & $(8)$ & $(8)$ & $(23)$ & $(23)$ & $(8)$ & $(8)$ & $(23)$ & $(23)$ & $(8)$ & $(8)$ \\
\hline $\mathrm{Si}$ & 6,560 & 6,609 & 2,658 & 2,756 & 6,630 & 6,573 & 2,734 & 2,722 & 6,538 & 6,712 & 2,689 & 2,702 \\
\hline $\mathrm{Ti}$ & 0,066 & 0,069 & 0,000 & 0,000 & 0,047 & 0,045 & 0,000 & 0,000 & 0,041 & 0,045 & 0,000 & 0,000 \\
\hline $\mathrm{Al}$ & 2,329 & 2,225 & 1,329 & 1,250 & 2,193 & 2,312 & 1,262 & 1,270 & 2,367 & 2,114 & 1,311 & 1,291 \\
\hline $\mathrm{Fe}$ & 2,314 & 2,378 & 0,013 & 0,016 & 2,221 & 2,258 & 0,000 & 0,012 & 2,258 & 2,187 & 0,000 & 0,010 \\
\hline $\mathrm{Mn}$ & 0,029 & 0,034 & 0,000 & 0,000 & 0,035 & 0,000 & 0,000 & 0,000 & 0,033 & 0,031 & 0,000 & 0,000 \\
\hline $\mathrm{Mg}$ & 1,801 & 1,777 & 0,000 & 0,000 & 2,000 & 1,911 & 0,000 & 0,000 & 1,856 & 1,998 & 0,000 & 0,000 \\
\hline $\mathrm{Ca}$ & 1,849 & 1,883 & 0,344 & 0,248 & 1,878 & 1,889 & 0,267 & 0,274 & 1,912 & 1,881 & 0,325 & 0,312 \\
\hline $\mathrm{Na}$ & 0,453 & 0,401 & 0,668 & 0,700 & 0,401 & 0,425 & 0,743 & 0,729 & 0,405 & 0,386 & 0,659 & 0,672 \\
\hline $\mathrm{K}$ & 0,068 & 0,071 & 0,000 & 0,000 & 0,047 & 0,051 & 0,000 & 0,000 & 0,060 & 0,049 & 0,000 & 0,000 \\
\hline $\mathrm{X}_{\mathrm{Fe}}$ & 0,562 & 0,572 & - & - & 0,526 & 0,542 & - & - & 0,549 & 0,523 & - & - \\
\hline $\mathrm{X}_{\mathrm{Mg}}$ & 0,438 & 0,428 & - & - & 0,474 & 0,458 & - & - & 0,451 & 0,477 & - & - \\
\hline$X_{\text {An }}$ & 0,780 & 0,800 & 0,340 & 0,262 & 0,808 & 0,799 & 0,265 & 0,273 & 0,804 & 0,812 & 0,330 & 0,317 \\
\hline
\end{tabular}

Примечание. Для плагиоклаза (Pl) приведены содержания анортитового компонента $X_{A n}=C a /(C a+N a+K)$, для роговой обманки (Hb) и биотита (Bt) - железистость $X_{\mathrm{Fe}}=\mathrm{Fe} /(\mathrm{Fe}+\mathrm{Mg})$. FeO представлено в форме суммарного железа. 0,00 - ниже порога обнаружения энергодисперсионного спектрометра. Структурные формульл минералов рассчитаны на определенное количество атомов кислорода, обозначенное как $n(O)$.

Note. Anorthite component content for plagioclase $(\mathrm{Pl})$ are given $X_{A n}=\mathrm{Ca} /(\mathrm{Ca}+\mathrm{Na}+\mathrm{K})$, the iron content for hornblende (Hb) and biotite $(\mathrm{Bt})-X_{\mathrm{Fe}}=\mathrm{Fe} /(\mathrm{Fe}+\mathrm{Mg})$. The total iron is shown in the FeO-form. 0,00 means that concentration is below the level of detection of SEM. Minerals structural formulas designed for a fixed number of oxygen atoms denoted as $n(O)$. 

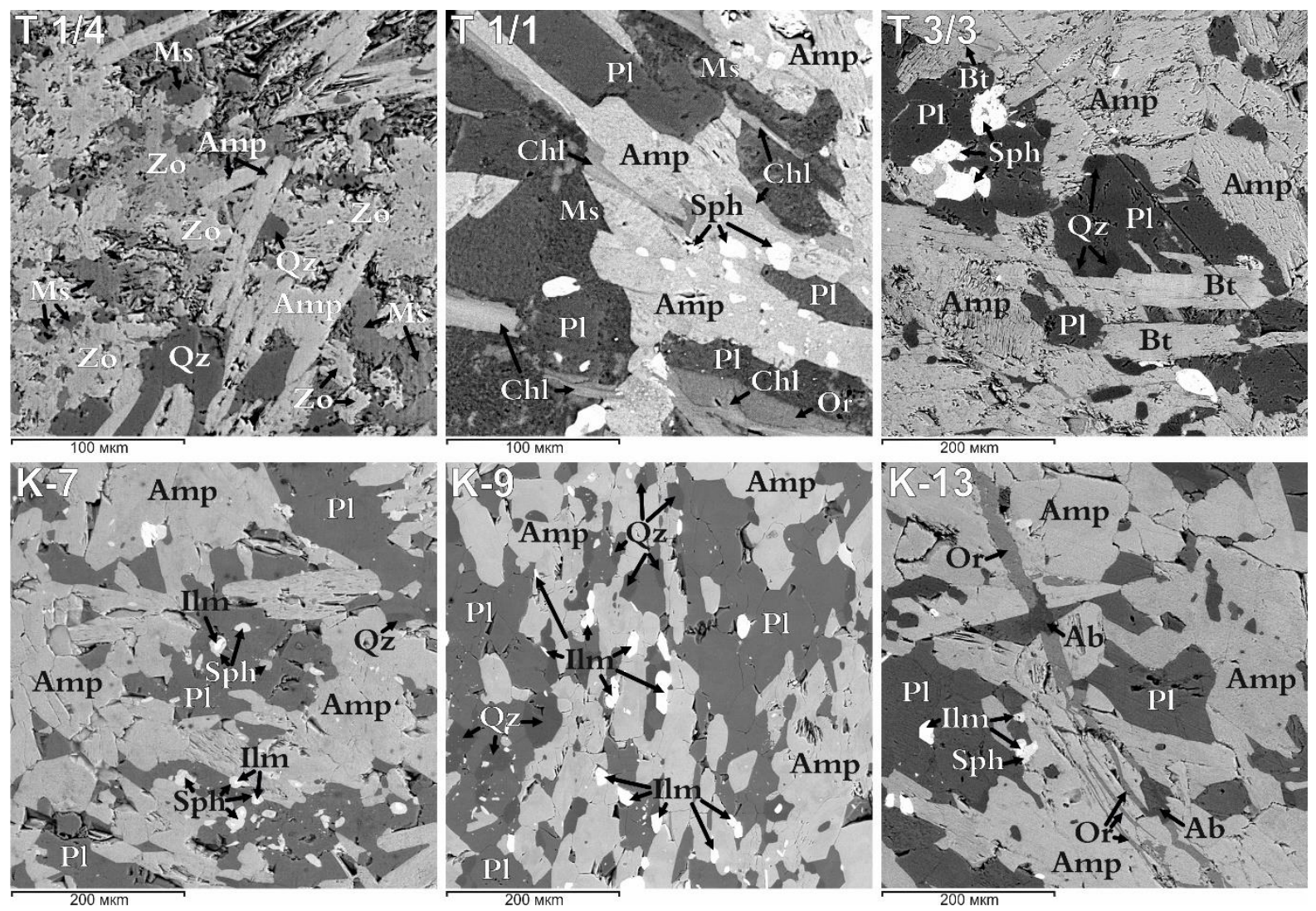

Рис. 2. Минеральный состав представительных образиов амфиболитовых проявлений в бассейнах рек Тырада (T) и Малая Кадра (К). Фотографии растровой электронной микроскопии, режим съемки BSE (детектор отраженных электронов). Ab-альбит, Aтр - амфибол, Bt - биотит, Chl-хлорит, Ilm - ильменит, Ms - мусковит, Or-ортоклаз, $\mathrm{Pl}$ - плагиоклаз, $Q z$ - квари, Spn - сфен, Zo - ияоизит

Fig. 2. Mineral composition of representative samples of amphibolite occurrences in the Tyrada $(T)$ and Malaya Kadra $(K)$ river basins. Photos of scanning electron microscopy. Mode-BSE (backscattered electrons detector). Ab - albite, Amp - amphibole, Bt-biotite, Chl-chlorite, Ilm-ilmenite, Ms - muscovite, Or-orthoclase, Pl-plagioclase, Qzquartz, Spn - sphene, Zo - zoisite

Согласно международной классификации [32], кальциевый амфибол представлен роговой обманкой, а в безплагиоклазовых образцах (Т-1/4) - актинолитом, со значениями железистости $\left(\mathrm{X}_{\mathrm{Fe}}\right)$ в диапазоне $0,48-0,58$ и $0,25-0,29$ соответственно. При этом на одном и том же участке образца этот показатель может варьировать от $0,01-0,03$, местами до 0,06 . Прослеживается прямая зависимость кремнистости от магнезиальности, которая укладывается в единый тренд эволюции составов амфиболов: от роговой обманки с незначительной примесью чермакитового компонента до кристаллизации актинолита (рис. 3). Во всех роговых обманках несущественные колебания содержаний $\mathrm{TiO}_{2} \quad\left(0,30-0,64\right.$ мас. \%), $\mathrm{K}_{2} \mathrm{O}$ $\left(0,22-1,00\right.$ мас. \%), $\mathrm{Na}_{2} \mathrm{O}(1,08-1,57$ мас. \%) и $\mathrm{MnO}$ (до 0,32 мас. \%) свидетельствует об их идентичности.

В рогообманковых образцах плагиоклаз незонален, состав его представительных зерен изменяется в диапазоне от олигоклаза до андезина $\left(\mathrm{X}_{\mathrm{An}}=0,28-0,38\right)$. В актинолитовом амфиболите (Т-1/4) плагиоклаз отсутствует полностью, цоизит выступает в качестве метаморфогенного продукта его изменения, а мусковит здесь представлен серицитом, большое количество которого, по всей вероятности, подтверждает наличие наложенного гидротермального метасоматоза. Также серицитизация краевых зон плагиоклаза прослеживается в рогообманковых амфиболитах (I, T-3/3). В качестве рудного компонента в ассоциацию входит ильменит. При этом зафиксирован факт его частичного или полного замещения сфеном (рис. 2, К-7, К-13 и Т-1/1, Т-3/3 соответственно). Очень редко встречаются зерна кварца, заполняющие пространство между зернами амфиболов и плагиоклазов и входящие в состав родоначальных базальтов. Калиевый полевой шпат представлен микроклином, местами ортоклазом (до 10 и 30 мол. \% альбита соответственно), выделяется поверх основной массы в виде линз и прожилок (или целой серии прожилок), размером не превышающих 0,05 мм, мощностью менее 40 мкм, и не имеет большого распространения. В отдельных представительных амфиболитах (II) встречаются криптопертиты, выраженные частичной метасоматической альбитизацией калиевого полевого шпата (рис. 2, К-13). Биотит редок, но представлен хорошо сформированными зернами. Их железистость $\left(\mathrm{X}_{\mathrm{Fe}}\right)$ варьирует от $0,42-0,43$ (обр. Т-1/1) до 0,52 (обр. Т-3/3), что сопоставимо с железистостью ассоциированных с ними амфиболов (табл. 1). Хлориты встречаются локально, преимущественно в рогообманковых амфиболитах метабазитового проявления в бассейне р. Тырада, и 
имеют в своем составе примеси $\mathrm{CaO}$ и $\mathrm{K}_{2} \mathrm{O}$ (до 1,5 и $4,5 \%$ соответственно). Их стехиометрическая формула соответствует рипидолиту (обр. Т-3/3) и пеннинупикнохлориту (обр. Т-1/1) со значениями железистости $\left(\mathrm{X}_{\mathrm{Fe}}\right)$ в узком диапазоне $0,42-0,48$ и $0,52-0,53$. Это сопоставимо с показателями железистости сопут- ствующих хлоритам биотита и роговой обманки, что подтверждает факт развития хлоритов по этим минералам. Игольчатые зерна актинолита и большое количество цоизита (Т-1/4) являются продуктами вторичных наложенных процессов, частично затронувших сформированный ранее парагенезис.
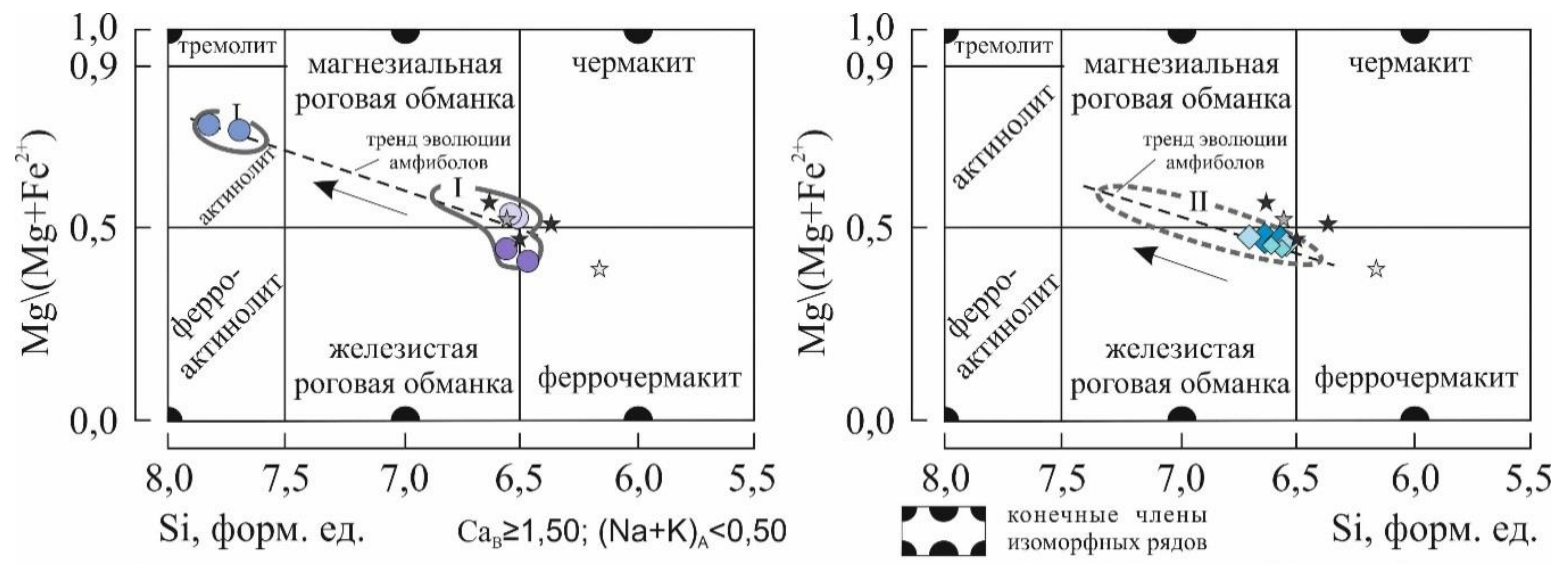

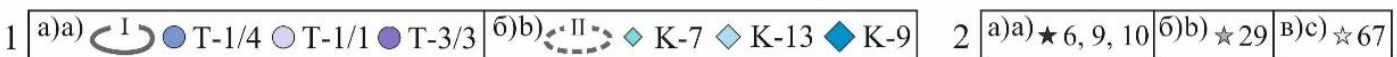

Рис. 3. Вариации химических составов амфиболов в метабазитах Центрально-Ангарского террейна Енисейского кряжа на классификационной диаграмме [32]. 1 - область распределения фигуративных точек химических составов амфиболов в представительных образиах метабазитовых проявлений Шумихинского комплекса 6 бассейнах: а) р. Тырада, б) р. Малая Кадра; 2 - фигуративные точки химических составов амфиболов в амфиболитах Гаревского метаморфического комплекса по данным И.И. Лиханова и В.В. Ревердатто [12] в бассейнах: a) среднего течения р. Гаревка; б) нижнего течения р. Гаревка; в) нижнего течения $p$. Тис

Fig. 3. Variations of the amphiboles chemical composition in amphibolites of Central-Angara terrane of the Yenisei Ridge in the classification chart [32]. 1 - area of data points distribution of amphibole chemical compounds in representative samples of Shumikhinskiy Complex metabasic manifestations in the basins of rivers: a) Tyrada, b) Malaya Kadra; 2 data points of amphiboles chemical composition in amphibolites of Garevsk metamorphic complex based on I.I Likhanov, V.V Reverdatto data [12] in the basins of: a) the middle river flow of the r. Garevka; $b$ ) the lower river flow of the $r$. Garevka; $c$ ) the lower river flow of the $r$. Tis

Результаты расчетов термодинамических параметров метаморфизма приведены на рис. 4 и в табл. 2. Для рогообманковых амфиболитов бассейнов рек Тырада и Малая Кадра значения Р-Т параметров варьируют в диапазоне $480-550{ }^{\circ} \mathrm{C}, 5-7$ кбар и $475-555^{\circ} \mathrm{C}, 5-7,5$ кбар соответственно. Следует отметить хорошую сходимость результатов по геотермобарометрам и слегка завышенные значения барометрии по геобарометру Хаммарсторма [28] 6,9-8,3 (I) и 6,0-8,4 (II) кбар, которые позволяют отметить такую же динамику увеличения давления в среднем до 2 кбар. Вышесказанное позволяет относить формирование исследуемых метабазитов к эпидот-амфиболитовой фации метаморфизма. Актинолитовые зерна в актинолитцоизитовом амфиболите (обр. Т-1/4) являются индикатором условий зеленосланцевой фации метаморфизма, теоретическое влияние которой подробно рассмотрено ниже. Ввиду отсутствия зерен плагиоклаза рассчитать геобарометрические значения не представляется возможным.

На диаграмме отношений $\mathrm{X}_{\mathrm{An}}(\mathrm{Pl}) / \mathrm{X}_{\mathrm{An}}(\mathrm{Amp})$ [26] прослеживается закономерное распределение вариа- тивных точек в сторону уменьшения температурного режима метаморфических процессов: от 550 до $475{ }^{\circ} \mathrm{C}$ для исследуемых амфиболитов (рис. 4, a). Очень близкие температурные значения отражает диаграмма отношений $\sum \mathrm{Al}(\mathrm{Amp})$ к $\mathrm{X}_{\mathrm{An}}(\mathrm{Pl})$ [25]: 525-555 ${ }^{\circ} \mathrm{C}$ при давлениях в 5-7,5 кбар (рис. 4, б). Такие же параметры барометрии показывает диаграмма отношений $\mathrm{Al} / \mathrm{Si}(\mathrm{Pl})$ к $\mathrm{Al} / \mathrm{Si}(\mathrm{Amp})$ [27], на которой они соответствуют 5,5-7,5 кбар (рис. 4, в). На диаграммах видна четкая динамика увеличения давления на фоне уменьшения температуры.

В табл. 3 приведены геотермические расчеты, основанные на химических данных составов хлоритов. Температура их образования, рассчитанная с помощью четырех термометров [29-31], показала неплохую сходимость. Хлориты представлены рипидолитом (обр. Т-3/3), пикнохлоритом и пеннином (обр. Т-1/1) и сформированы в температурном интервале 344-261 ${ }^{\circ} \mathrm{C}$ и $269-199{ }^{\circ} \mathrm{C}$ соответственно. На классификационной диаграмме [33] хорошо выражена прямая зависимость $\mathrm{Si}$ к $\mathrm{X}_{\mathrm{Fe}}\left(\right.$ и $\mathrm{X}_{\text {total }}$ ) по мере уменьшения температуры кристаллизации (рис. 5). 

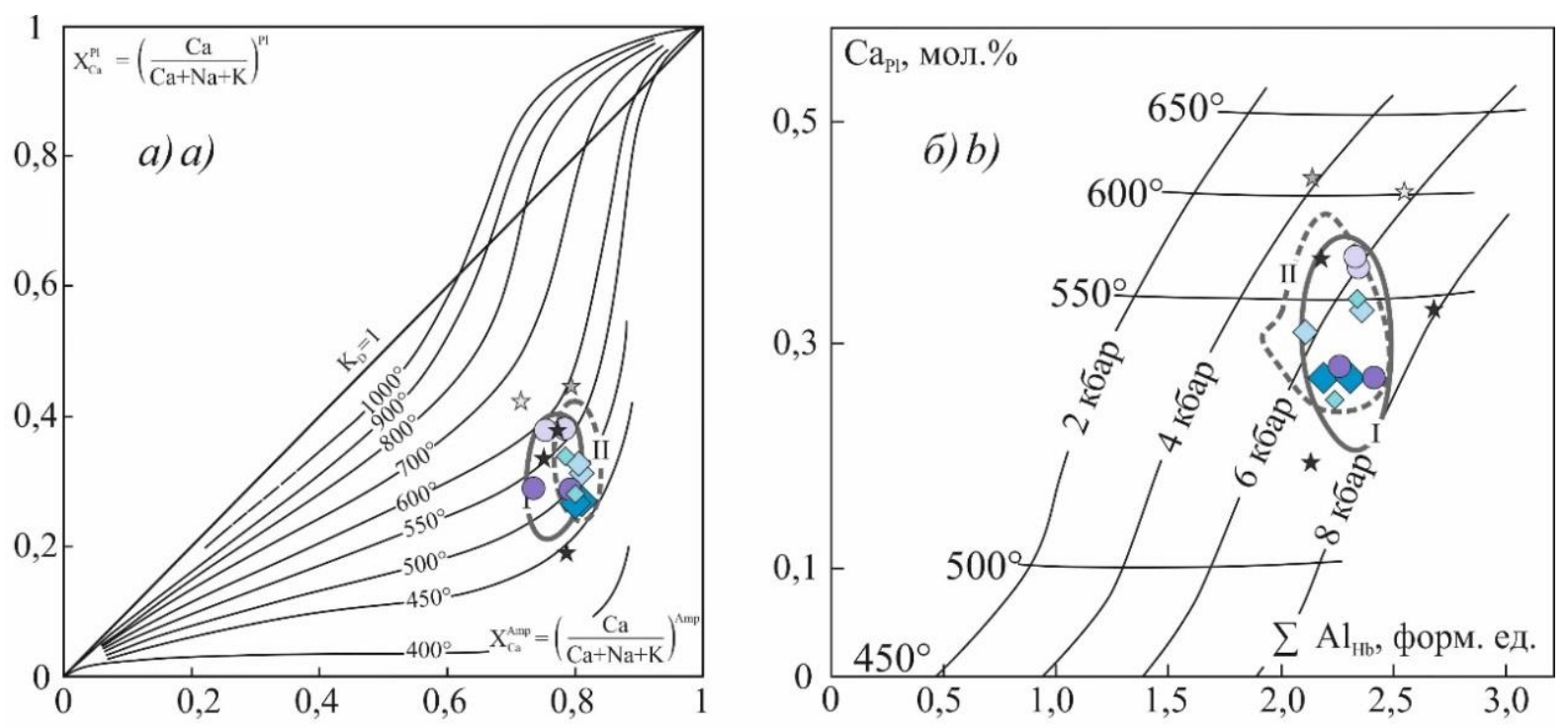

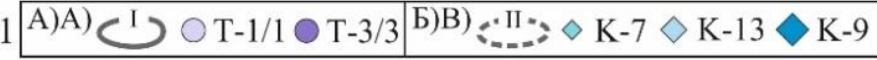

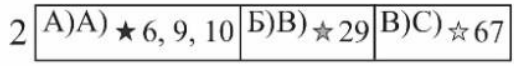

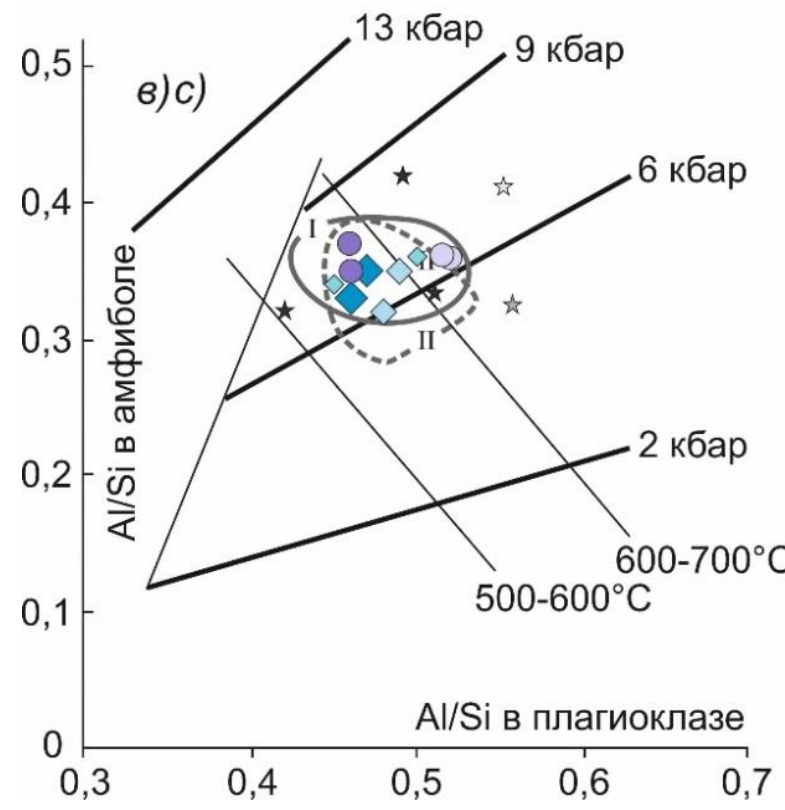

Рис. 4. Р-Т условия метаморфизма на амфибол-плагиоклазовых геотермобарометрах. Диаграммы отношений: a) $\mathrm{Ca} /(\mathrm{Ca}+\mathrm{Na}+\mathrm{K})$ в амфиболе и $\mathrm{Ca} /(\mathrm{Ca}+\mathrm{Na}+\mathrm{K})$ в плагиоклазе [26]; б) суммарного Al в амфиболе и Са в плагиоклазе [25]; в) Al/Si плагиоклаза и амфибола [27]. 1 - область распределения фигуративных точек представительных образиов метабазитовых проявлений Шумихинского комплекса в бассейнах: А) р. Тырада, Б) р. Малая Кадра; 2 - фигуративные точки образиов амфиболитов Гаревского метаморфического комплекса по данным И.И. Лиханова и В.В. Ревердатто [12] в бассейнах: А) среднего течения р. Гаревка; Б) нижнего течения $p$. Гаревка; В) нижнего течения $p$. Тис

Fig. 4. $P-T$ conditions of metamorphism on amphibole-plagioclase geothermobarometers. Diagrams of ratio: a) $\mathrm{Ca} /(\mathrm{Ca}+\mathrm{Na}+\mathrm{K})$ in amphibole and $\mathrm{Ca} /(\mathrm{Ca}+\mathrm{Na}+\mathrm{K})$ in plagioclase [26]; b) total Al in amphibole and $\mathrm{Ca}$ in plagioclase [25]; c) Al/Si of plagioclase and amphibole [27]. 1 -distribution area of data of representative samples of metabasite manifestations from the Shumikhinskiy complex in the river basins of: A) Tyrada, B) Malaya Kadra; 2 - data of amphibolites from the Garevsk metamorphic complex based on data of I.I. Likhanov, V.V Reverdatto [12] in the basins of: A) the middle reaches of the Garevka; B) the lower reaches of the Garevka; $C$ ) the lower reaches of the Tis 
Таблица 2. Оиенки Р-Т условий метаморфизма метабазитовых образований Заангарья по минеральным геотермобарометрам

Table 2. Estimates of P-T conditions of metabasic Transangare formations metamorphism using mineral geothermobarometers

\begin{tabular}{|c|c|c|c|c|c|}
\hline \multirow{2}{*}{$\begin{array}{l}\text { Номер } \\
\text { образца } \\
\text { Sample } \\
\text { number }\end{array}$} & & 2 & 3 & 4 \\
\hline & $\mathrm{T},{ }^{\circ} \mathrm{C}$ & $\begin{array}{l}\text { P, кбар } \\
\text { P, kbar }\end{array}$ & $\mathrm{T},{ }^{\circ} \mathrm{C}$ & \multicolumn{2}{|c|}{$\begin{array}{l}\text { P, кбар } \\
\text { P, kbar }\end{array}$} \\
\hline & \multicolumn{5}{|c|}{$\begin{array}{l}\text { Ортоамфиболиты шумихинского метапикрит- } \\
\text { базальтового комплекса в бассейне р. Тырада } \\
\text { Prthoamphibolites of the Shumikhinsky metapicritic- } \\
\text { basalt complex from the Tyrada river basin }\end{array}$} \\
\hline $\mathrm{T}-1 / 1$ & $\sim 550$ & $5-7$ & $545-550$ & $\sim 6-7$ & $6,91-8$ \\
\hline \multirow[t]{2}{*}{$\mathrm{T}-3 / 3$} & $525-530$ & $\sim 7$ & $480-500$ & $\sim 7$ & $7,13-7,8$ \\
\hline & \multicolumn{5}{|c|}{$\begin{array}{l}\text { Ортоамфиболиты шумихинского метапикрит- } \\
\text { базальтового комплекса в бассейне р. Малая Кадра } \\
\text { Orthoamphibolites of the Shumikhinsky metapicritic- } \\
\text { basalt complex from the Malaya Kadra river basin }\end{array}$} \\
\hline K-7 & $540-555$ & $5,5-7$ & $525-545$ & $\sim 6-7$ & $6,88-8,3$ \\
\hline K-9 & $540-545$ & & $485-500$ & $\sim 5,5-7$ &, $04-7$, \\
\hline \multirow[t]{2}{*}{ K-13 } & $540-545$ & $5,5-7,5$ & $475-500$ & $\sim 6-7,5$ & $6,55-8,3$ \\
\hline & \multicolumn{5}{|c|}{$\begin{array}{c}\text { Ортоамфиболиты гаревского метаморфического } \\
\text { комплекса в бассейне нижне-среднего течения р. } \\
\text { Гаревка } \\
\text { Orthoamphibolites of the Garevsky metamorphic } \\
\text { complex from the lower-middle course Garevka river } \\
\text { basin }^{5}\end{array}$} \\
\hline 6 & $\sim 570$ & $\sim 5$ & $\sim 570$ & $\sim 6$ & 7,02 \\
\hline 9 & $\sim 520$ & $\sim 7$ & $\sim 450$ & $\sim 7$ & 6,79 \\
\hline 10 & $\sim 570$ & $\sim 8$ & $\sim 550$ & $\sim 8$ & 9,54 \\
\hline \multirow[t]{2}{*}{29} & $\sim 605$ & $\sim 4$ & $\sim 600$ & $\sim 5$ & 6,82 \\
\hline & \multicolumn{5}{|c|}{$\begin{array}{l}\text { Ортоамфиболиты гаревского метаморфического } \\
\text { комплекса в бассейне нижнего течения р. Тис } \\
\text { Orthoamphibolites of the Garevsky metamorphic } \\
\text { complex from the lower course Tys river basin }{ }^{5}\end{array}$} \\
\hline 67 & $\sim 600$ & $\sim 6$ & $\sim 650$ & $\sim 7$ & 8,88 \\
\hline
\end{tabular}

Примечание. Геотермобарометры: 1 - Amp-Pl [26]; геотермометр: 2 - Amp-Pl [25]; геобарометры: 3 Aтр-Pl [27], 4 - [28], 5 - данные по [12].

Note. Geothermobarometers: $1-A m p-P l$ [26]; geothermometers: 2 - Amp-Pl [25]; geobarometers: 3 Amp-Pl [27], 4-[28], 5-based on data of [12].

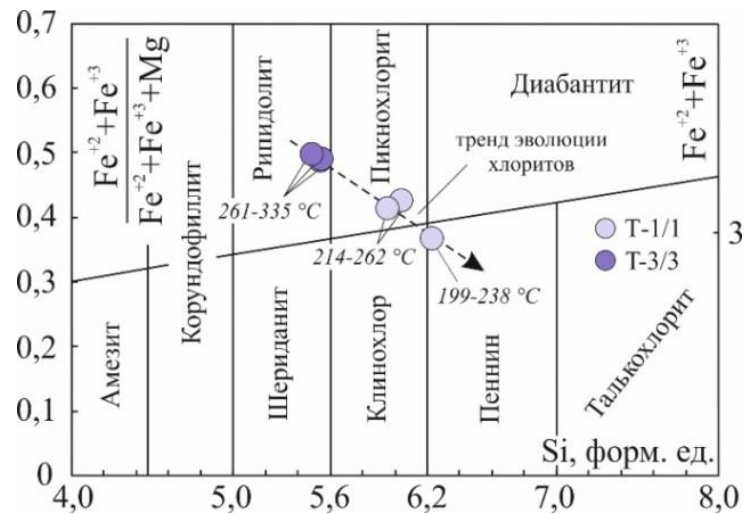

Pис. 5. Классификационная диаграмма хлоритов (Si $\kappa$ $X_{F e}$ ) по [33] и их температура кристаллизации. Фигуративные точки составов хлоритов в представительных образиах метабазитового проявления Шумихинского комплекса в бассейне $p$. Тырада: рипидолит (обр. Т-3/3) и пикнохлорит-пеннин (обр. T-1/1). Стрелкой отображен тренд эволюиии составов хлоритов на фоне снижения температуры их кристаллизации
Таблица 3. Химический состав (мас. \%), структурные формулы и температуры кристаллизачии представительных хлоритов $\left(T,{ }^{\circ} \mathrm{C}\right)$

Table 3. Chemical composition (wt. \%), crystallization temperature $\left(T,{ }^{\circ} \mathrm{C}\right)$ and the structural chlorites formula

\begin{tabular}{|c|c|c|c|c|c|c|}
\hline $\begin{array}{l}\text { Компонент } \\
\text { Component }\end{array}$ & \multicolumn{3}{|c|}{$\mathrm{T}-1 / 1$} & \multicolumn{3}{|c|}{$\mathrm{T}-3 / 3$} \\
\hline $\mathrm{SiO}_{2}$ & 30,11 & 28,68 & 29,2 & 25,47 & 25,56 & 24,54 \\
\hline $\mathrm{TiO}_{2}$ & 0,00 & 0,00 & 0,00 & 0,00 & 0,00 & 0,00 \\
\hline $\mathrm{Al}_{2} \mathrm{O}_{3}$ & 17,28 & 18,84 & 18,55 & 19,82 & 19,52 & 19,21 \\
\hline $\mathrm{FeO}_{\text {total }}$ & 21,25 & 23,74 & 24,55 & 26,76 & 26,97 & 26,55 \\
\hline $\mathrm{MnO}$ & 0,00 & 0,23 & 0,00 & 0,00 & 0,00 & 0,00 \\
\hline $\mathrm{MgO}$ & 16,53 & 15,94 & 15,07 & 13,77 & 14,01 & 13,5 \\
\hline $\mathrm{CaO}$ & 1,47 & 0,00 & 1,24 & 0,00 & 0,00 & 0,00 \\
\hline $\mathrm{Na}_{2} \mathrm{O}$ & 0,00 & 0,00 & 0,00 & 0,00 & 0,00 & 0,00 \\
\hline $\mathrm{K}_{2} \mathrm{O}$ & 1,25 & 0,78 & 0,00 & 0,00 & 0,00 & 0,00 \\
\hline $\begin{array}{c}\text { Сумма } \\
\text { Amount }\end{array}$ & 87,89 & 88,21 & 88,61 & 85,81 & 86,07 & 83,79 \\
\hline $\mathrm{n}(\mathrm{O})$ & 28 & 28 & 28 & 28 & 28 & 28 \\
\hline $\mathrm{Si}$ & 6,220 & 5,950 & 6,033 & 5,533 & 5,545 & 5,481 \\
\hline $\mathrm{Ti}$ & 0,000 & 0,000 & 0,000 & 0,000 & 0,000 & 0,000 \\
\hline $\mathrm{Al}^{\mathrm{IV}}$ & 1,780 & 2,050 & 1,967 & 2,467 & 2,455 & 2,519 \\
\hline $\mathrm{Al}^{\mathrm{VI}}$ & 2,427 & 2,556 & 2,551 & 2,608 & 2,536 & 2,538 \\
\hline $\mathrm{Fe}_{\text {total }}$ & 3,671 & 4,119 & 4,242 & 4,862 & 4,893 & 4,959 \\
\hline $\mathrm{Mn}$ & 0,000 & 0,040 & 0,000 & 0,000 & 0,000 & 0,000 \\
\hline $\mathrm{Mg}$ & 5,089 & 4,929 & 4,641 & 4,459 & 4,530 & 4,494 \\
\hline $\mathrm{Ca}$ & 0,325 & 0,000 & 0,275 & 0,000 & 0,000 & 0,000 \\
\hline $\mathrm{Na}$ & 0,000 & 0,000 & 0,000 & 0,000 & 0,000 & 0,000 \\
\hline K & 0,329 & 0,206 & 0,000 & 0,000 & 0,000 & 0,000 \\
\hline $\mathrm{X}_{\mathrm{Fe}}$ & 0,419 & 0,455 & 0,478 & 0,522 & 0,519 & 0,525 \\
\hline \multicolumn{7}{|c|}{$\mathrm{T}^{\circ} \mathrm{C}$} \\
\hline A & 225 & 268 & 255 & 335 & 333 & 344 \\
\hline $\mathrm{B}^{1}$ & 207 & 235 & 226 & 279 & 278 & 285 \\
\hline $\mathrm{B}^{2}$ & 238 & 269 & 262 & 318 & 317 & 324 \\
\hline $\mathrm{C}$ & 199 & 225 & 214 & 263 & 261 & 268 \\
\hline
\end{tabular}

Примечание. $X_{F e}=F_{\text {total }} /\left(\mathrm{Fe}_{\text {total }}+\mathrm{Mg}\right)$, геотермометры: $A$ [29]; B [30]: 1 - без поправки на $A l^{I V}, 2$ - с поправкой на $A l^{I V} ; C$ [31]. FеO представлено в форме суммарного железа. 0,00 - ниже порога обнаружения энергодисперсионного спектрометра. Структурные формуль минералов рассчитаны на определенное количество атомов кислорода, обозначенное как $n(O)$.

Note. $X_{F e}=F e_{\text {total }} /\left(F_{\text {total }}+M g\right)$, geothermometers: $A$ [29]; $B$ [30]: 1 - without adjusting on $A l^{I V}, 2$ - with adjusting on $A l^{I V} ; C[31]$. The total iron is in the FeO-form. 0,00 means that concentration is below the level of detection of SEM. Minerals structural formulas designed for a fixed number of oxygen atoms denoted as $n(O)$.

Fig. 5. Chlorite classification diagram based on [33] and the temperature of chlorite crystallization. Chemical composition points of chlorites in representative samples of metabasite manifestation from the Shumikhinskiy complex in the Tyrada river basin: ripidolite (sample T-3/3) and pycnochlorite-pennine (sample T-1/1). The arrow shows the change in chlorite compositions against the background of a temperature decrease of their crystallization 


\section{Обсуждение результатов}

На сегодняшний день существует несколько точек зрения относительно условий формирования и возраста ортоамфиболитов шумихинского метапикрит (метакоматиит)-метабазальтового комплекса. По одним данным метабазитовые ассоциации образовались в геодинамической обстановке растяжения в условиях гранулитовой и гранат-силлиманитовой зон амфиболитовой фации (750-850 ${ }^{\circ} \mathrm{C}$ и 8-9 кбар) и имеют позднеархейский возраст по Rb-Sr изотопии ( 2531 млн лет) [13]. Более современные исследования включают шумихинские ортоамфиболиты в единый полиметаморфический комплекс, сформированный в обстановке растяжения и сжатия континентальной коры в позднем рифее ( 980-880 млн лет) в условиях амфиболитовой и эпидот-амфиболитовой фаций метаморфизма $\left(581-631{ }^{\circ} \mathrm{C}, 7,7-8,6\right.$ кбар и $461-547{ }^{\circ} \mathrm{C}$ и 3,9-4,9 кбар соответственно) $[15,21,22]$. В ходе данного исследования вышеизложенные результаты позволяют выделить как минимум два неопротерозойских эволюционных события, отразившихся на метабазитовых породных комплексах Заангарья.

Первое событие повлекло за собой образование единого устоявшегося парагенезиса исследуемых метабазальтов в условиях метаморфизма низкотемпературных зон амфиболитовой фации в температурном интервале $475-550{ }^{\circ} \mathrm{C}$ и давлении 5-7,5 кбар. Значительный рост давления при небольшом уменьшении температуры можно объяснить утолщением земной коры в результате надвиговых процессов на общем фоне эксгумации тектонических блоков в верхние структурные этажи. В этом случае метаморфизованный блок был лежачим относительно плоскости сместителя, а из этого следует, что направление смещения происходило в сторону Сибирского кратона, и данное метаморфическое событие стоит относить ко второму коллизионному этапу с участием надвигов, датированному 800 млн лет назад [18, 20, 21, 34, 35]. Несоответствие этой цифре полученных данных по Ar-Ar-изотопии (707-675 млн лет) указывает на перестройку изотопной системы амфибола в результате повторного теплового воздействия на амфиболиты после или во врем их остывания.

Со вторым событием связан процесс калишпатизации, повлекший за собой образование микроклина/ортоклаза при температуре $\leq 500^{\circ} \mathrm{C}$ с дальнейшим наложением процессов альбитизации, имеющих автометасоматическую природу возникновения. Этап частичной гранитизации имеет унаследованный характер, вероятно, при участии высокотемпературных флюидов при заложении неопротерозойских лейкогранитов, в значительной степени обогащенных калием. Распространенные в пределах ТатароИшимбинской зоны разломов синколлизионные аяхтинские (760-750 млн лет) и/или анорогенные татарские (680-630 млн лет) гранитоиды, входящие в татаро-аяхтинский гранитовый комплекс ( $\left.\gamma \mathrm{R}_{3} \mathrm{ta}\right)$ [36], могли стать причиной омоложения возраста исследуемых метабазитов. Частичная хлоритизация и актинолитизация (344-199 $\left.{ }^{\circ} \mathrm{C}\right)$, а также последующие ста- дии более низкотемпературных гидратермальных изменений, включающие в себя процессы серицитизации и соссюритизации, являются показателем краткосрочных фаз гидротермального воздействия в условиях остывания коллизионных гранитоидов. Наличие или отсутствие этих вторичных изменений в метабазальтах объясняется локальностью гидротерм, неравномерно разогревающих породный комплекс. Этому свидетельствует прямая зависимость $\mathrm{Si}$ к $\mathrm{X}_{\mathrm{Fe}}$ в хлоритах по мере уменьшения температуры их кристаллизации. В совокупности с локальным присутствием зерен актинолита (обр. Т-1/4) образование хлоритов подтверждает факт вторичного влияния нового источника разогрева, вероятно, спровоцировавшего открытие изотопной системы в амфиболе, в результате чего произошло омоложение возраста амфиболитов. Верхний порог температур нагрева мог быть выше и соответствовать эффективной температурной зоне закрытия изотопной системы в амфиболах равной $420{ }^{\circ} \mathrm{C}$ [34], но в связи со своей краткосрочностью не повлекший значительных изменений.

Докембрийские амфиболитовые тела в толщах позднеархейской (?) малогаревской метасерии (шумихинский метапикртит-базальтовый комплекс?) также выделяются в пределах гаревского метаморфического комплекса (ГМК) вдоль разрывных нарушений Приенисейской зоны разломов [12]. Данные метабазитовые образования также ассоциируют с неопротерозойскими лейкогранитами возрастом 750-720 млн лет, относящимся к постколлизионному глушихинскому гранитоидному комплексу $\left(\mathrm{l} \mathrm{R}_{3} \mathrm{~g}\right)$ [36], что вызывает интерес в контексте данного исследования. Формирование микроклин-цоизитовых ортоамфиболитов авторы описывают в два этапа. На первом этапе породы погружаются в среднюю часть континентальной коры и перекристаллизовываются в условиях средней-верхней части амфиболитовой фации регионального метаморфизма $(\mathrm{P}=7,7-8,6$ кбар и $\mathrm{T}=582-631{ }^{\circ} \mathrm{C}$; 960 млн лет). Второй этап имеет сходство с эволюционными событиями, описанными выше в рамках данного исследования: позднерифейский коллизионный метаморфизм в условиях эпидот-амфиболитовой фации (P=3,9-4,9 кбар, $\mathrm{T}=461-547^{\circ} \mathrm{C} ; \sim 880$ млн лет) и поздний низкотемпературный метаморфизм мусковит-хлоритовой субфации фации зеленых сланцев, отражающий низкотемпературные изменения средне-высокотемпературных пород ГМК при их эксгумации [15]. По данным химических составов минеральных фаз, приведенным авторами указанной статьи, были пересчитаны Р-Т условия образования амфиболитов с использованием вышеописанных геотермобарометров. Полученные результаты (табл. 2, рис. 4) имеют схождение с результатами вышеприведенных авторов. Схожесть химического состава амфиболов ГМК и его преобразование в процессе их перекристаллизации, которое укладывается в общий тренд закономерного изменения роговых обманок исследуемых амфиболитов (рис. 3), а также одинаковые минеральные ассоциации, сформированные наложенными процессами, 
позволяют утверждать, что сравниваемые метабазитовые комплексы являются производными одних и тех же геодинамических событий, происходивших в Заангарье $880-800$ млн лет назад.

\section{Выводы}

1. Наряду со сходством состава петрогенных и редких элементов [23] одинаковый минеральный парагенезис заангарских амфиболитов в бассейнах рек Тырада и Малая Кадра позволяет говорить о них, как об одном амфиболитовом комплексе. А термодинамические условия их образования указывают на то, что они являются производными одного и того же метаморфического процесса.

2. Проведенные анализы и расчеты позволяют выделить основную фазу эволюции метаморфитов, соответствующую эпидот-амфиболитовой фации коллизионного метаморфизма и действующую без перерыва на протяжении длительного времени в условиях надвига. Это может быть сопряжено с

\section{СПИСОК ЛИТЕРАТУРЬ}

1. Pearce J.A. Geochemical fingerprinting of oceanic basalts with applications to ophiolite classification and the search for Archean oceanic crust // Lithos - 2008. - № 100. - P. 14-48.

2. Богатиков О.А., Коваленко В.И., Шарков Е.В. Магматизм, тектоника, геодинамика Земли // Труды Института геологии рудных месторождений, петрографии, минералогии и геохимии (новая серия). Вып. 3 / под ред. В.В. Ярмолюк. - М. Наука, 2010. - 606 c.

3. Dilek Y., Furnes H. Ophiolite genesis and global tectonics: geochemical and tectonic fingerprinting of ancient oceanic lithosphere // Geological Society of America Bulletin. - 2011. № 123. - P. 387-411.

4. Попов Н.В., Лиханов И.И., Ножкин А.Д. Мезопротерозойский гранитоидный магматизм в Заангарской части енисейского кряжа: результаты U-Pb-исследований // Доклады академии наук - 2010. - Т. 431. - № 4. - С. 509-515.

5. Козлов П.С., Лиханов И.И. Мезо-неопротерозойская эволюция Заангарья Енисейского кряжа // Геодинамика раннего докембрия: сходства и различия с фанерозоем - Петрозаводск: Карельский научный центр Российской академии наук, 2017. - C. $121-126$

6. Докембрийская эволюция Заангарья Енисейского кряжа как отражение тектонических событий на западной окраине Сибирского кратона / А.А. Крылов, И.И. Лиханов, А.Д. Ножкин, В.В. Ревердатто, П.С. Козлов // Петрология магматических и метаморфических комплексов - Томск: Томский центр научно-технической информации, 2017. - С. 265-270.

7. Ernst R.E. Large igneous provinces. - Cambridge: Cambridge University Press, 2014. - $630 \mathrm{p}$.

8. Рабочая схема корреляции магматических и метаморфических комплексов Енисейского кряжа / Т.Я. Корнев, Л.К. Качевский, А.Д. Ножкин, В.М. Даценко, А.А. Стороженко, К.А. Заблоцкий, А.П. Романов // Региональные схемы корреляции магматических и метаморфических комплексов Алтае-Саянской складчатой области. - Новосибирск: СНИИГГИМС, 1999. C. $17-46$.

9. Неопротерозойский рифтогенный и внутриплитный магматизм Енисейского кряжа как индикатор процессов распада Родинии / А.Д. Ножкин, О.М. Туркина, Т.Б. Баянова, Н.Г. Бережная, А.Н. Ларионов, А.А. Постников, А.В. Травин, Р.Е. Эрнст // Геология и геофизика - 2008. - Т. 49. - № 7. C. $666-688$.

10. Ножкин А.Д., Качевский Л.К., Дмитриева Н.В. Поздненеопротерозойская рифтогенная метариолит-базальтовая ассоциация глушихинского прогиба (Енисейский кряж): петрогеохимический состав, возраст и условия образования // Геология и геофизика - 2013. - Т. 54. - № 1. - С. 58-71. аккрецией отколовшегося от Сибирского кратона микроконтинента к Центрально-Ангарскому террейну около 800 млн лет назад [18, 35, 37].

3. Вторичное воздействие на сформированный парагенезис могло быть спровоцировано заложением развитых в регионе синколлизионных/постколлизионных неопротерозойских гранитоидов (760-630 млн лет назад) [36-41], что, вероятно, послужило причиной омоложения абсолютного возраста исследуемых амфиболитов (707-675 млн лет).

Вышеизложенное укладывается в полиметаморфическую модель формирования современного облика юго-западного обрамления Сибирского кратона, отражающую процессы рассеянного рифтогенеза при участии плюмовой активности, инициированного распадом суперконтинента Родиния [42-44], и коллизионные процессы в пределах трансформных разломов на завершающей стадии гренвильских тектонических событий [45].

11. Туркина О.М., Ножкин А.Д. Геохимия и вопросы генезиса метабазитов из гранулито-гнейсового комплекса АнгароКанского блока (Юго-запад Сибирского кратона) // Геохимия - 2014. - № 10. - С. 892-906.

12. Лиханов И.И., Ревердатто В.В. Неопротерозойские комплексы-индикаторы континентального рифтогенеза как свидетельство процессов распада Родинии на западной окраине Сибирского кратона // Геохимия - 2015. - № 8. - С. 675-694.

13. Государственная геологическая карта Российской Федерации. Масштаб 1:1000000 (третье поколение). Серия АнгароЕнисейская. Лист О-46 - Красноярск. Объяснительная записка. СПб.: Картографическая фабрика ВСЕГЕИ, 2009. - 500 с.

14. Чингасанская серия неопротерозоя Енисейского кряжа: Новые данные о возрасте и условиях формирования / А.Д. Ножкин, А.А. Постников, А.В. Наговицин, А.В. Травин, А.М. Станевич, Д.С. Юдин // Геология и геофизика - 2007. - Т. 48. - № 12. C. $1307-1320$.

15. Тектонометаморфическая эволюция гаревского полиметаморфического комплекса Енисейского кряжа / П.С. Козлов, И.И. Лиханов, В.В. Ревердатто, С.В. Зиновьев // Геология и геофизика - 2012. - Т. 53. - № 11. - С. 1476-1496.

16. Верниковский В.А., Верниковская А.Е. Тектоника и эволюция гранитоидного магматизма Енисейского кряжа // Геология и геофизика - 2006. - № 1. - С. 35-52.

17. Neoproterozoic accretionary and collisional events on the western margin of the Siberian Craton: new geological and geochronological evidence from the Yenisei Ridge / V.A. Vernikovsky, A.E. Vernikovskaya, A.B. Kotov, E.B. Salnikova, V.P. Kovach // Tectonophysics. - 2003. V. 375. - № 1-4. - P. 147-168.

18. Гренвильские тектонические события и эволюция Енисейского кряжа, западная окраина Сибирского кратона / И.И. Лиханов, А.Д. Ножкин, В.В., Ревердатто П.С. Козлов // Геотектоника. - 2014. - Т. 50. - № 5. - С. 32-53.

19. Kuzmichev A.B., Sklyarov E.V. The Precambrian of Transangaria, Yenisei ridge (Siberia): Neoproterozoic microcontinent, grenvilleage orogen, or reworked margin of the Siberian craton? // Journal of Asian Earth Sciences - 2016. - V. 115. - № 1. - P. 419-441.

20. Первые петрологические свидетельства субдукции на западной окраине Сибирского кратона / И.И. Лиханов, П.С. Козлов, К.А. Савко, С.В. Зиновьев, А.А. Крылов // Доклады академии наук. - 2019. - Т. 484. - № 2. - С. 209-2014.

21. Likhanov I.I., Nozhkin A.D., Savko K.A. Accretionary tectonics of rock complexes in the western margin of the Siberian craton // Geotectonics. - 2018. - V. 52. - P. 22-44.

22. Likhanov I.I. Mass-transfer and differential element mobility in metapelites during multistage metamorphism of Yenisei ridge, Siberia // Geological society special publication. - 2019. V. 478. - P. 89-115 
23. Метабазитовые породы Среднего Заангарья, Енисейский кряж: e-morb реликты неопротерозойской литосферы / В.В. Врублевский, Р.Н. Никитин, П.А. Тишин, А.В. Травин // Литосфеpa. - 2017. - T. 17. - № 5. - С. $67-84$.

24. Заангарский щелочной интрузив, Енисейский кряж: $\mathrm{Rb}-\mathrm{Sr}-$, $\mathrm{Sm}-\mathrm{Nd}$-изотопный возраст пород и источники фельдшпатоидных магм в позднем докембрии / А.М. Сазонов, В.В. Врублевский, И.Ф. Гертнер, А.В. Федорова, В.В. Гавриленко, Е.А. Звягина, С.И. Леонтьев // Доклады Академии наук. 2007. - T. 413. - № 16. - C. 798-802.

25. Плюснина Л.П. Экспериментальное исследование равновесий метабазитов, геотермобарометрия // Эксперимент в решении актуальных задач в геологии: сб. науч. трудов. - М.: Наука, 1986. - C. $174-183$

26. Перчук Л.Л. Равновесия породообразующих минералов. - М. Наука, 1970. - 390 c

27. Ферштатер Г.Б. Эмпирический плагиоклаз-рогообманковый барометр // Геохимия. - 1990. - № 3. - С. 328-335.

28. Hammarstrom J.M. Aluminum in hornblende: an empirica igneous geobarometer // American Mineralogist. - 1986. № 71. - P. 1297-1313.

29. Cathelineau M. Cation site in chlorites and illites as a function of tempreture // Clay Minerals. - 1988. - № 23. - P. 471-485.

30. Kranidiotis P., Maclean W.H. Systematics of chlorite alteration at the Phelps Dodge massive sulfide deposit // Economic Geology. 1987. - № 82. - P. 1898-1911.

31. Fayek M., Kyser T.K. Characteristics of auriferous and barren fluids associated with the Proterozoic // Economic Geology. 1995. - № 90. - P. 385-406

32. Leake B.E. Nomenclature of amphiboles: report of the subcommittee on amphiboles of the commission on new minerals and mineral names of the international mineralogical association (CNMMN IMA) // PROC. RMS. - 1997. - № 6. - P. 82-102.

33. Hey M.H. A new review of the chlorites // Mineralogical Magazine. - 1954. - № 30. - P. 277-292.

34. Травин А.В. Термохронология субдукционно-коллизионных, коллизионных событий Центральной Азии: дис. ... д-ра наук. - Новосибирск, 2016. - 320 с

35. Лиханов И.И., Ревердатто В.В., Козлов П.С. Коллизионные метаморфические комплексы енисейского кряжа: особенности эволюции, возрастные рубежи и скорость эксгумации // Геология и геофизика. -2011 . - № 10. - С. 1593-1611.

36. Лейкогранитный магматизм а-типа в эволюции континентальной коры западного обрамления Сибирского кратона
А.Е. Верниковская, В.А. Верниковский, Е.Б. Сальникова, А.Б. Котов, В.П. Ковач, А.В. Травин, М.Т. Вингейт // Геология и геофизика. -2007 . - Т. 48. - № 1. - С. 5-21.

37. Верниковский В.А., Верниковская А.Е. Тектоника и эволюция гранитоидного магматизма Енисейского кряжа // Геология и геофизика. - 2006. - № 1. - С. 35-52.

38. Likhanov I.I., Santosh M. A-type granites in the western margin of the Siberian craton: implications for breakup of the Precambrian supercontinents Columbia/Nuna and Rodinia // Precambrian Research. - 2019. - V. 328. - P. 128-145.

39. Likhanov I.I., Nozhkin A.D., Reverdatto V.V. Early stages of the evolution of the paleoasian ocean on the western margin of the Siberian craton: evidence from geochronological and geochemical studies of Yenisei ridge // Doklady earth sciences - 2017. V. 476. - P. 1089-1093.

40. Likhanov I.I., Reverdatto V.V., Savko K.A. Bimodal intraplate magmatism of the Yenisei ridge as evidence of breakup of rodinia and opening of the paleoasian ocean at the western margin of the Siberian craton // Doklady earth sciences. - 2017. - V. 476. P. 1217-1221.

41. Late vendian postcollisional leucogranites of Yenisei ridge / A.D. Nozhkin, I.I. Likhanov, V.V. Reverdatto, S.V. Zinoviev, N.V. Dmitrieva, T.B. Bayanova, P.S. Kozlov, N.V. Popov // Doklady earth sciences. - 2017. - V. 474. - P. 674-679.

42. Meert J.G., Powell C.M. Assembly and break-up of Rodinia: introduction to the special volume // Precambrian Research. 2001. - № 110. - P. 1-8.

43. Meert J.G., Torsvik T.H. The making and unmaking of a supercontinent: Rodinia revisited // Tectonophysics. - 2003. № 375. - P. 261-288.

44. Kuznetsov N.B., Meert J.G., Romanyuk T.V. Ages of detrital zircons (U/Pb, LA-ICP-MS) from the latest neoproterozoic-middle cambrian(?) Asha group and early devonian takaty formation, the southwestern urals: a test of an australia-baltica connection within Rodinia // Precambrian Research. - 2014. - V. 244. - № 1. P. 288-305.

45. Ножкин А.Д., Попов Н.В., Дмитриева Н.В., Стороженко А.А., Васильев Н.Ф. Неопротерозойские коллизионные S-гранитоиды Енисейского кряжа: петрогеохимические особенности, U-Pb, $\mathrm{Ar}-\mathrm{Ar}, \mathrm{Sm}-\mathrm{Nd}$ изотопные данные // Геология и геофизика. 2015. - T. 56. - № 5. - C. 881-889.

Поступила 03.06.2020 г.

\section{Информация об авторах}

Никитин P.Н., инженер-исследователь Центра коллективного пользования «Аналитический центр геохимии природных систем» Национального исследовательского Томского государственного университета. 
UDC 551.251:552.13:552.16

\title{
MINERALOGICAL FEATURES AND P-T CONDITIONS OF METAMORPHISM OF NEOPROTEROZOIC METABASITES FROM THE TYRADA AND MALAYA KADRA RIVER BASINS, YENISEI RIDGE
}

\author{
Radim N. Nikitin, \\ radim.geo@mail.ru \\ National Research Tomsk State University, \\ 36, Lenin avenue, Tomsk, 634050, Russia.
}

\begin{abstract}
The relevance of the work. Today it is considered that metabasite rock associations widespread in the Trans-Angara part of the Yenisei Ridge are products of rifting processes caused by activity of plume and breakdown of the Rodinia supercontinent during 1100-700 Ma. In this case, data on their absolute age are the subject of discussion. The paper considers the Neoproterozoic metamorphic events using thermodynamic features of formation of the studied amphibolite manifestations as an example and their place in geodynamic model of formation of the Yenisei Ridge, as well as the role of syn/postcollisional granitoid magmatism in age rejuvenation of Transangar amphibolites.
\end{abstract}

The aim of the research is to establish the main mineral paragenesis of amphibolites and their secondary mineralization; determine the thermodynamic conditions of metamorphism and its main stages; correlate the nature of metamorphism with the metamorphic events of the region and determine its role in the formation of the modern appearance of the Yenisei Ridge; identify the reasons responsible for the mismatch between the age of the studied amphibolites according to the Ar-Ar isotopy and the accepted dating the Zaangarya metabasalts. Objects: amphibolites of the Shumikhinsky metapicritic-basalt complex, which is a part of the malogarevskaya metamorfic series of the Late Archean age (?) occurring among carbonate rocks and crystalline schists in the valleys of the Tyrad and Malaya Kadra river basins and the Tei and Panimba tributaries respectively.

Methods. Chemical composition of the mineral phases was obtained using an analytical complex for scanning electron microscopy and microanalysis based on a TESCAN VEGA II LMU scanning electron microscope, combined with an Oxford INCA Energy 350 in the Center for Collective Use «Analytical Center of the Geochemistry of Natural Systems» of the National Research Tomsk State University. Based on the data the crystal chemical formulas of minerals were calculated, classification and geothermobarometric diagrams were constructed.

Results. The authors established general paragenesis of amphibolites of the studied manifestations: $H b l+P I\left(X_{A n}=0,28-0,38\right)+Q z+l l m$ (Sph)+Fsp with secondary local development of Act, Zo, Bt, Ms and Chl. Thermodynamic parameters of metamorphism of metabasites correspond to the conditions of low-temperature zones of the amphibolite facies $\left(555-475{ }^{\circ} \mathrm{C}, 5-7,5 \mathrm{kbar}\right)$ with the dynamics of pressure increase against the general background of gradual cooling. Amphibolites are derivatives of collision metamorphism ( 880-800 Ma), which appeared in the accretionary conditions of previously split tectonic blocks of the Siberian craton. The local development of potassium feldspar, actinolitization, and chloritization $\left(344-199{ }^{\circ} \mathrm{C}\right)$ refers to superimposed processes under reheating conditions and may be associated with the final stage of the Grenville tectonic events accompanied by syn/postcollisional granitoid magmatism ( $\left.\mathrm{Y} R_{3} \mathrm{ta}, 760-630 \mathrm{Ma}\right)$. It could become a cause of age rejuvenation of the studied metabasites (707-675 Ma).

\section{Key words:}

Amphibolites, neoproterozoic collision metamorphism, epidote-amphibolite facies, P-T conditions, age of metamorphism, Yenisei Ridge.

\section{REFERENCES}

1. Pearce J.A. Geochemical fingerprinting of oceanic basalts with applications to ophiolite classification and the search for Archean oceanic crust. Lithos, 2008, no. 100, pp. 14-48.

2. Bogatikov O.A., Kovalenko V.I., Sharkov E.V. Magmatizm tektonika, geodinamika Zemli. Trudy Instituta geologii rudnykh mestorozhdeniy, petrografii, mineralogii $i$ geokhimii (novaya seriya) [Magmatism, tectonics, geodynamics of the Earth Proceedings of the Institute of Geology of Ore Deposits, Petrography, Mineralogy and Geochemistry (new series)]. Moscow, Nauka Publ., 2010. 606 p.

3. Dilek Y., Furnes H. Ophiolite genesis and global tectonics: geochemical and tectonic fingerprinting of ancient oceanic lithosphere. Geological Society of America Bulletin, 2011, no. 123, pp. 387-411.

4. Popov N.V., Likhanov I.I., Nozhkin A.D. Mezoproterozoyskiy granitoidny magmatizm $\mathrm{v}$ Zaangarskoy chasti yeniseyskogo kryazha: rezultaty $\mathrm{U}-\mathrm{Pb}$-issledovaniy [Mesoproterozoic granitoid magmatism in the Zaangarsky part of the Yenisei Ridge: results of U-Pb studies]. Doklady akademii nauk, 2010, vol. 431, no. 4, pp. 509-515.

5. Kozlov P.S., Likhanov I.I. Mezo-neoproterozoyskaya evolyutsiya Zaangarya Yeniseyskogo kryazha [Meso-Neoproterozoic evolution of the Zaangarye of the Yenisei Ridge]. Geodinamika rannego dokembriya: skhodstva $i$ razlichiya s fanerozoyem [Geodynamics of early Precambrian: similarities and differences with the Phanerozoic]. Petrozavodsk, Karelia scientific centre of the RAS, 2017. pp. 121-126.

6. Krylov A.A., Likhanov I.I., Nozhkin A.D., Reverdatto V.V., Kozlov P.S. Dokembriyskaya evolyutsiya Zaangarya Yeniseyskogo kryazha kak otrazheniye tektonicheskikh sobytiy na zapadnoy okraine Sibirskogo kratona [Precambrian evolution of the Zaangar of the Yenisei Ridge as a reflection of tectonic events on the western outskirts of the Siberian Craton]. Petrologiya magmaticheskikh i metamorfichesikkh kompleksov [Petrology of igneous and metamorphic complexes]. Tomsk, Tomsk center of science-technical information, 2017. pp. 265-270.

7. Ernst R.E. Large igneous provinces. Cambridge, Cambridge University Press, 2014. $630 \mathrm{p}$.

8. Kornev T.Ya., Kachevskiy L.K., Nozhkin A.D., Datsenko V.M., Storozhenko A.A., Zablotskiy K.A., Romanov A.P. Rabochaya skhema korrelyatsii magmaticheskikh i metamorficheskikh kompleksov Yeniseyskogo kryazha [Working correlation scheme for magmatic and metamorphic complexes of the Yenisei Ridge]. Regionalnye skhemy korrelyatsii magmaticheskikh i metamorficheskikh kompleksov Altae-Sayanskoy skladchatoy oblasti [Regional correlation schemes of magmatic and metamorphic complexes of the Altai-Sayan folded region]. Novosibirsk, SNIIGGIMS Publ., 1999. pp. 17-46.

9. Nozhkin A.D., Tupkina O.M., Bayanova T.B. Bepezhnaya N.G., Lapionov A.N., Poctnikov A.A., Tpavin A.V., Epnct P.E. Neoprotepozoyskiy piftogenny i vnutpiplitny magmatizm Yeniseyckogo kpyazha kak indikator protsessov raspada Rodinii [The Neoproterozoic riftogenic and intraplate magmatism of the 
Yenisei ridge as an indicator of the decay processes of the Line]. Geologiya i geofizika, 2008, vol. 49, no. 7, pp. 666-688.

10. Nozhkin A.D., Kachevskiy L.K., Dmitrieva N.V. Pozdneneoproterozoyskaya riftogennaya metariolit-bazaltovaya assotsiatsiya glushikhinskogo progiba (Yeniseyskiy kryazh): petrogeokhimicheskiy sostav, vozrast i usloviya obrazovaniya [Late Neoproterozoic riftogenic metariolite-basalt association of the Glushikhinsky trough (Yenisei Ridge): petrogeochemical composition, age, and formation conditions]. Geologiya i geofizika, 2013, vol. 54, no. 1, pp. 58-71.

11. Turkina O.M., Nozhkin A.D. Geokhimiya i voprosy genezisa metabazitov iz granulito-gneysovogo kompleksa AngaroKanskogo bloka (Yugo-zapad Sibirskogo kratona) [Geochemistry and questions of the genesis of metabasites from the granulitegneiss complex of the Angara-Kan block (South-West of the Siberian craton)]. Geokhimiya, 2014, no. 10, pp. 892-906.

12. Likhanov I.I., Reverdatto V.V. Neoproterozoyskie kompleksyindikatory kontinentalnogo riftogeneza kak svidetelstvo protsessov raspada Rodinii na zapadnoy okraine Sibirskogo kratona [Neoproterozoic indicator complexes of continental riftogenesis as evidence of the decay of Rodinia on the western edge of the Siberian craton]. Geokhimiya, 2015, no. 8, pp. 675-694.

13. Gosudarstvennaya geologicheskaya karta Rossiyskoy Federatsii. Masshtab 1:1000000 (tretye pokoleniye). Seriya AngaroYeniseyskaya. List O-46. Obyasnitelnaya zapiska [State geological map of the Russian Federation. Scale 1:1000000 (third generation). Series Angara-Yenisei. Sheet O-46. Explanatory note]. St. Petersburg, Kartograficheskaya fabrika VSEGEI Publ., 2009. $500 \mathrm{p}$.

14. Nozhkin A.D., Poctnikov A.A., Nagovitsin A.V., Tpavin A.V. Stanevich A.M., Yudin D.S. Chingasanskaya seriya neoproterozoya Yeniseyckogo kpyazha: Novye dannye o vozpaste i usloviyakh fopmipovaniya [The Chingasan neoproterozoic series of the Yenisei Ridge: New data on the age and conditions of formation]. Geologiya i geofizika, 2007, vol. 48, no. 12, pp. 1307-1320.

15. Kozlov P.S., Likhanov I.I., Reverdatto V.V., Zinovyev S.V. Tektonometamorficheskaya evolyutsiya garevskogo polimetamorficheskogo kompleksa Yeniseyskogo kryazha [Tectonometamorphic evolution of the Garevsky polymetamorphic complex of the Yenisei Ridge]. Geologiya i geofizika, 2012, vol. 53, no. 11, pp. 1476-1496.

16. Vernikovskiy V.A., Vernikovskaya A.E. Tektonika i evolyutsiya granitoidnogo magmatizma Yeniseyskogo kryazha [Tectonics and evolution of granitoid magmatism of the Yenisei Ridge]. Geologiva i geofizika, 2006, no. 1, pp. 35-52.

17. Vernikovsky V.A., Vernikovskaya A.E., Kotov A.B., Salnikova E.B. Kovach V.P. Neoproterozoic accretionary and collisional events on the western margin of the Siberian Craton: new geological and geochronological evidence from the Yenisei Ridge. Tectonophysics, 2003, vol. 375, no 1-4, pp. 147-168.

18. Likhanov I.I., Nozhkin A.D., Reverdatto V.V., Kozlov P.S. Grenvil'skiye tektonicheskiye sobytiya i evolyutsiya Yeniseyskogo kryazha, zapadnaya okraina Sibirskogo kratona [Grenville tectonic events and the evolution of the Yenisei Ridge, the western outskirts of the Siberian craton]. Geotektonika, 2014, vol. 50, no. 5, pp. 32-53.

19. Kuzmichev A.B., Sklyarov E.V. The Precambrian of Transangaria, Yenisei ridge (Siberia): Neoproterozoic microcontinent, grenvilleage orogen, or reworked margin of the Siberian craton? Journal of Asian Earth Sciences, 2016, vol. 115, no. 1, pp. 419-441.

20. Likhanov I.I., Krylov A.A., Kozlov P.S., Zinoviev S.V., Savko K.A. The first petrological evidence for subduction at the western margin of the Siberian craton. Doklady earth sciences, 2019, vol. 484, no. 1, pp. 79-83.

21. Likhanov I.I., Nozhkin A.D., Savko K.A. Accretionary tectonics of rock complexes in the western margin of the Siberian craton. Geotectonics, 2018, vol. 52, pp. 22-44.

22. Likhanov I.I. Mass-transfer and differential element mobility in metapelites during multistage metamorphism of Yenisei ridge, Siberia. Geological society special publication, 2019, vol. 478, pp. 89-115.

23. Vrublevskiy V.V., Nikitin R.N., Tishin P.A., Travin A.V Metabasite rocks of the Middle Zaangarye, Yenisei Ridge: e-morb relics of the Neoproterozoic lithosphere. Litosfera, 2017, vol. 17, no. 5, pp. 67-84. In Rus.
24. Sazonov A.M., Vrublevskiy V.V., Gertner I.F., Fedorova A.V., Gavrilenko V.V., Zvyagina E.A., Leontyev S.I. Zaangarskiy shchelochnoy intruziv, Yeniseyskiy kryazh: $\mathrm{Rb}-\mathrm{Sr}, \mathrm{Sm}-\mathrm{Nd}-$ izotopny vozrast porod i istochniki feldshpatoidnykh magm v pozdnem dokembrii [Zaangarsk alkaline intrusion, Yenisei Ridge: $\mathrm{Rb}-\mathrm{Sr}, \mathrm{Sm}-\mathrm{Nd}$ isotopic age of rocks and sources of feldspathoid magmas in Late Precambrian]. Doklady Akademii nauk, 2007, vol. 413 , no. 16 , pp. $798-802$.

25. Plyusnina L.P. Eksperimentalnoe issledovanie ravnovesiy metabazitov, geotermobarometriya [An experimental study of the equilibrium of metabasites, geothermobarometry]. Moscow, Nauka Publ., 1986. pp. 174-183.

26. Perchuk L.L. Ravnovesiva porodoobrazuyushchikh mineralov [Equilibrium of rock-forming minerals]. Moscow, Nauka Publ., 1970. $390 \mathrm{p}$.

27. Fershtater G.B. Empiricheskiy plagioklaz-rogoobmankovyy barometr [Empirical plagioclase-tax-barometer barometer]. Geokhimiya, 1990, no. 3, pp. 328-335.

28. Hammarstrom J.M. Aluminum in hornblende: an empirical igneous geobarometer. American Mineralogist, 1986, no. 71, pp. 1297-1313.

29. Cathelineau M. Cation site in chlorites and illites as a function of tempreture. Clay Minerals, 1988, no. 23, pp. 471-485.

30. Kranidiotis P., Maclean W.H. Systematics of chlorite alteration at the Phelps Dodge massive sulfide deposit. Economic Geology, 1987, no. 82, pp. 1898-1911.

31. Fayek M., Kyser T.K. Characteristics of auriferous and barren fluids associated with the Proterozoic. Economic Geology, 1995, no. 90 , pp. $385-406$.

32. Leake B.E. Nomenclature of amphiboles: report of the subcommittee on amphiboles of the commission on new minerals and mineral names of the international mineralogical association (CNMMN IMA). PROC. RMS, 1997, no. 6, pp. 82-102.

33. Hey M.H. A new review of the chlorites. Mineralogical Magazine, 1954 , no. 30, pp. 277-292.

34. Travin A.V. Termokhronologiya subduktsionno-kollizionnykh, kollizionnykh sobytiy Tsentralnoy Azii. Dis. Dokt. nauk [Thermochronology of subduction-collision, collision events of Central Asia. Dr. Diss.]. Novosibirsk, 2016. 320 p.

35. Likhanov I.I., Reverdatto V.V., Kozlov P.S. Kollizionnye metamorficheskie kompleksy yeniseyskogo kryazha: osobennosti evolyutsii, vozrastnye rubezhi i skorost eksgumatsii [Collision metamorphic complexes of the Yenisei Ridge: evolutionary features, age lines, and the rate of exhumation]. Geologiya $i$ geofizika, 2011, no. 10, pp. 1593-1611.

36. Vernikovskaya A.E., Vernikovskiy V.A., Sal'nikova E.B., Kotov A.B., Kovach V.P., Travin A.V., Vingeyt M.T. Leykogranitnyy magmatizm a-tipa $\mathrm{v}$ evolyutsii kontinental'noy kory zapadnogo obramleniya Sibirskogo kratona [Leucogranite magmatism of atype in the evolution of the continental crust of the western frame of the Siberian craton]. Geologiya i geofizika, 2007, vol. 48, no 1. pp. 5-21.

37. Vernikovskiy V.A., Vernikovskaya A.E. Tektonika i evolyutsiya granitoidnogo magmatizma Yeniseyskogo kryazha [Tectonics and evolution of granitoid magmatism of the Yenisei Ridge]. Geologiya i geofizika, 2006, no 1, pp. 35-52.

38. Likhanov I.I., Santosh M. A-type granites in the western margin of the Siberian craton: implications for breakup of the precambrian supercontinents Columbia/Nuna and Rodinia. Precambrian Research, 2019, vol. 328, pp. 128-145.

39. Likhanov I.I., Nozhkin A.D., Reverdatto V.V. Early stages of the evolution of the paleoasian ocean on the western margin of the siberian craton: evidence from geochronological and geochemical studies of Yenisei ridge. Doklady earth sciences, 2017, vol. 476, pp. 1089-1093.

40. Likhanov I.I., Reverdatto V.V., Savko K.A. Bimodal intraplate magmatism of the Yenisei ridge as evidence of breakup of Rodina and opening of the paleoasian ocean at the western margin of the Siberian craton. Doklady earth sciences, 2017, vol. 476, pp. 1217-1221.

41. Nozhkin A.D., Likhanov I.I., Reverdatto V.V., Zinoviev S.V., Dmitrieva N.V., Bayanova T.B., Kozlov P.S., Popov N.V. Late vendian postcollisional leucogranites of Yenisei ridge. Doklady earth sciences, 2017, vol. 474, pp. 674-679. 
42. Meert J.G., Powell C.M. Assembly and break-up of Rodinia: introduction to the special volume. Precambrian Research, 2001, no. 110 , pp. $1-8$.

43. Meert J.G., Torsvik T.H. The making and unmaking of a supercontinent: Rodinia revisited. Tectonophysics, 2003, no. 375, pp. 261-288.

44. Kuznetsov N.B., Meert J.G., Romanyuk T.V. Ages of detrital zircons (U/Pb, LA-ICP-MS) from the latest neoproterozoic-middle Cambrian(?) Asha group and early Devonian takaty formation, the southwestern Urals: a test of an Australia-Baltica connection within Rodinia. Precambrian Research, 2014, vol. 244, no. 1, pp. 288-305.

Information about the authors
45. Nozhkin A.D., Popov N.V., Dmitriyeva N.V., Storozhenko A.A., Vasilyev N.F. Neoproterozoyskiye kollizionnyye S-granitoidy Eniseyskogo kryazha: petrogeokhimicheskiye osobennosti. U-Pb. Ar-Ar. Sm-Nd izotopnyye dannyye [Neoproterozoic collisional Sgranitoids of the Yenisei Ridge: petrogeochemical features, U-Pb, Ar-Ar, Sm-Nd isotopic data]. Geologiya i geofizika, 2015, vol. 56, no. 5, pp. $881-889$.

Received: 3 June 2020.

Radim N. Nikitin, research engineer, National Research Tomsk State University. 